\title{
Origin and mechanisms of high salinity in Hombolo Dam and groundwater in Dodoma municipality Tanzania, revealed
}

\author{
Ceven Shemsanga ${ }^{1,4}$ - Alfred Nzibavuga Nyarubakula Muzuka ${ }^{1}$ Lawrance Martz ${ }^{2}$. \\ Hans Charles Komakech ${ }^{1} \cdot$ Eliapenda Elisante $^{3} \cdot$ Marry Kisaka $^{4} \cdot$ Cosmas Ntuza $^{5}$
}

Received: 29 June 2015/Accepted: 24 April 2017/Published online: 12 May 2017

(c) The Author(s) 2017. This article is an open access publication

\begin{abstract}
The Hombolo dam (HD), in central Tanzania, is a shallow reservoir characterized by high salinity that limits its use for human activities. The origin of the salinity, mechanisms of reaching and concentrating in the dam remain unclear. These were assessed using hydrogeochemical facies, water type evolutions and mapping. The source of HD salinity was identified to be shallow groundwater (SG) and runoff from a seasonal floodplain with $\mathrm{NaCl}$-rich lithological materails, along Little Kinyasungwe River that feeds the dam. The $\mathrm{NaCl}$-rich lithological units, about 5-7 km upstream of the dam, were highly concentrated with $\mathrm{NaCl}$ to the extent that the local community was commercially separating table salt from them. The physicochemical parameters from these $\mathrm{NaCl}$-rich lithological materials were well represented in HD and nearby groundwater sources, which suggests active water interactions. Water type evolution and surface hydrology assessments clearly showed that SG in the salty-floodplain was influenced by evaporation (ET) and was periodically carried to the HD. Clearly; HD water had high chemical similarity with the nearby SG. This agrees with previous studies that HD is partly fed by the local aquifer. However, this is the first
\end{abstract}

Ceven Shemsanga

7ceven@gmail.com

1 Department of Water and Environmental Sciences and Engineering, Nelson Mandela African Institution of Science and Technology-Tengeru, Arusha, Tanzania

2 Department of Geography and Planning, University of Saskatchewan, Saskatoon, Canada

3 Department of Physical Sciences, Sokoine University of Agricultute, 3038, Chuo Kikuu, Morogoro, Tanzania

4 Department of Environmental Engineering and Management, University of Dodoma, Dodoma, Tanzania

5 Hombolo Irrigation Scheme, Dodoma, Tanzania attempt at mapping its physical origin. The origin of $\mathrm{HD}$ salinity was further supported by the spatial distribution of electrical conductivity (EC), where very high EC (up to $21,230 \mu \mathrm{Scm}^{-1}$ ) was recorded in $\mathrm{SG}$ within the $\mathrm{NaCl}$-rich lithological unit while water sources far away from the $\mathrm{NaCl}-$ rich materials had much lower EC values. Thus, the study disagrees with previous conclusions that HD salinity was sorely due to high dam surface ET but is primarily due to geological reasons. Comparisons of HD with a nearby Matumbulu dam (MD), another earthen dam in climatologically similar settings, reveals that MD water was less saline/ mineralised. This further shows that HD high salinity is most likely a geologic phenomenon, but local climatic factors, namely high ET, decreasing rainfall and warming trends are likely to have concentrated the salts further. Although HD is widely/ideally used for grape vine irrigation, it was clearly revealed that its prolonged usage would potentially affect the soil and grape productivity due to high salinity.

Keywords · Hombolo dam · salinity · groundwater · origin · livelihood

\section{Introduction}

Water is a universal solvent in which most matters dissolve (Kumar 2013; Parmar 2013). Thus, its chemical compositions depend on environmental and aseptic conditions and processes that potentially modify it as it moves along the catchment (Biswas 2004; Kumar 2013). Thus, the best way to manage water quality is tracing its catchment movements (Parmar 2013). In recent years, however, global freshwater quality has been worsened by humans and ongoing climate change impacts (Taylor et al. 2012, Shemsanga et al. 2015). Yet, even without these problems, 
water quality/salinity management; is difficult as water molecules constantly move between different states and locations (Biswas 2004 2008).

In arid and semi-arid zones, water quality limits water supply options and uses (Prasanna et al. 2011). Thus, management of such valuable water resources calls for an understanding of its hydro-geochemistry and evolutions (Prasanna et al. 2011). Since different water uses/needs require specific quality, the origin of freshwater quality is of global interest (Ghalibaf and Moussavi 2014). For instance, while high water salinity affects soil/crop productivity, hard water causes scum, curd, yellowing of fabrics, scales in heaters/boilers and pipes. It also toughens vegetables and does not easily form lather with soap. Yet, too soft water is often corrosive (Mulwa et al. 2013). Thus, assessing the origin of water quality and allocating its suitable uses is crucial (Mulwa et al. 2013).

Although Hombolo dam (HD) high salinity has been debated for over 20 years, its origin remains unclear. While some studies associated it with high dam surface evaporation (ET) (Shindo 1991), others linked it to geological origin, but would not clearly indicate the mechanisms (Nkotagu 1996). All, previous studies, however, did not show the spatial source of the salts that would end up being concentrated by ET nor assess water suitability for various uses. Furthermore, available data at Hombolo Irrigation Scheme (HIS), which started in 1995, do not suggest a significant rainfall dilution and that the dam retains high salinity year-round (Shindo 1991; Shemsanga et al. 2015). This suggests that the water feeding the dam could already be saline, details of which remains to be investigated.

Yet, irrigation officers and irrigators reported unexplained progressive increases in HD salinity recently. This has reduced seasonality for which HD is used for irrigation (mostly grape). Village leaders, elders and fishermen argue of reduced HD fish harvests recently while well owners around HD report increased pumpage of saltier water recently (Personal communication with Mr. Ntuza of HIS). Yet, HD is a vital discharge site of Makutupora aquifer, the main aquifer supplying water to Dodoma municipality (DM) (Shindo 1991). Thus, for the integrity of the city, the origin of salts, their evolutions, movements and mechanisms of concentrating in HD and groundwater must be understood. Nevertheless, these remain unclear which impedes sustainable water resources management.

Despite the importance of HD, no current study has assessed sources of its high salinity, transportation and concentrating mechanisms in the dam. This study, therefore, intended to critically investigate and map the origin and mechanisms of high salinity in the HD catchment so as to help the local populace to support their major livelihood support systems that mostly depend on it.

\section{Case study description}

This study was carried in HD catchment within Dodoma Municipality, which is located between 775,000-945,000 and 9,280,000-9,380,000 (UTM, Arc 1960) (Fig. 1). Climatologically, it is a semi-arid region with low uni-modal rains ( $550 \mathrm{~mm} / \mathrm{yr}$.) falling between October and May. Mean daily temperature is lowest in July (about $13.0^{\circ} \mathrm{C}$ ) and highest in November (about $30.6{ }^{\circ} \mathrm{C}$ ). ET rate averages about 2000 $\mathrm{mmyr}^{-1}$; roughly 4 times annual rainfall (Shemsanga et al. 2015). Except for HD, the area lacks permanent surface water bodies and the river network is largely seasonal flowing only during wet seasons and a few weeks thereafter. Thus, human activities are heavily reliant on HD and groundwater. Geologically, it occurs in the fractured, faulted and tectonically active crystalline basement of the Dodoma craton. The metasedimentary rocks are mainly quartzites, ironstones, micaceous quartzites, quartzo-feldspathic schists and ferruginous quartzites (Nkotagu 1996, Shemsanga et al., 2015).

\section{Methodology}

Twenty-seven (27) water samples from boreholes (BHs), HD, Matumbulu dam (MD), shallow dug wells (SDWs) and the major tributaries leading to Little Kinyasungwe River (LKR) and which flows to HD; were collected in March, 2014. HD was also sampled during the peak of the dry season, i.e. September, 2014 to enable useful water quality parameters temporal comparisons. Water quality comparisons between $\mathrm{HD}$ and MD, another earthen dam in similar environmental settings (about $38 \mathrm{~km}$ apart), were also done. Scichem STC multi-parameter tester kit was used for in situ measurements of $\mathrm{pH}$, total dissolved solids (TDS) and electrical conductivity (EC). Sampling sites were marked by handheld GPS receiver, Garmin eTrex 20 (UTM, Arc 1960). Water samples were analyzed at the Ministry of Water Laboratory in Dodoma following standard methods described by Elisante and Muzuka (2016). Laboratory results were checked for consistency via electrical balance error (EBE) (Eq. 1) and were required to be $<10$ (Kaka et al. 2011). Surfer V.11 ${ }^{\circledR}$ was used to extrapolate $\mathrm{EC}$ and $\mathrm{pH}$ spatial patterns using kriging tool (Fig. 2a, b). Water suitability for irrigation was assessed using standard indices (Eqs. 2-5), all concentrations (conc.) expressed in $\mathrm{meq} / \mathrm{L}$. Domestic water was assessed based on national (URT 2007) and World Health Organization (WHO 2008) permissible limits (PLs) and maximum permissible limits (MPLs) (Table 1). Since local water sources are mainly used for grape irrigation, and because grapes are sensitive to high salinity, chloride and sodium toxicity; their suitability was assessed using standard methods described by Goldammer (2015). Grapes require $\mathrm{Na}^{+}$and $\mathrm{Cl}^{-}$in irrigation water 

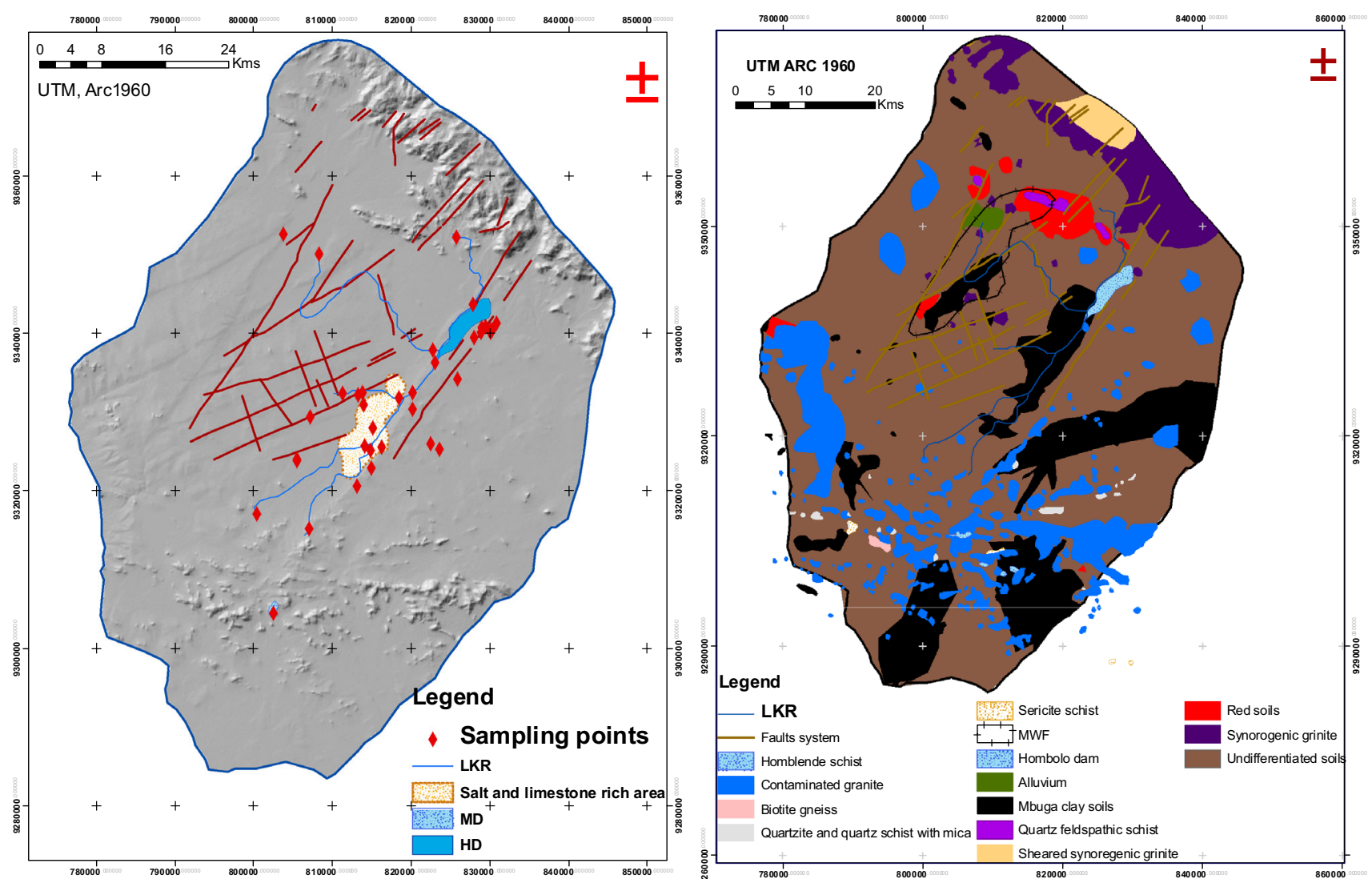

Fig. 1 A map showing the location of the study area, sampling points, geological map and Hombolo and Matumbulu dams of Dodoma Municipality-Tanzania

be to $<20.01$ and $<3.95 \mathrm{meq} / \mathrm{L}$, respectively, while $\mathrm{pH}$ should range from 6 to 8.5. Generally, EC and $\mathrm{Cl}^{-}$of (0-2000 and $<3.95)(20,001-30,000$ and 3.95- $<14.95)$, and ( $>3000$ and $>14.95)\left(\mu \mathrm{Scm}^{-1}\right.$ and meq/L), cause, no, medium and severe problems for grape vine productivity, respectively (Goldammer 2015).

$$
\begin{aligned}
\% \mathrm{EBE}= & \left(\sum \text { Cations }- \text { Anions }\right) / \\
& \sum\left(\text { Cations }+\sum \text { Anions }\right)(\mathrm{meq} / \mathrm{L}) \times 100
\end{aligned}
$$

Graphical compositions of cations and anions in water were assessed using a diamond-shaped PIPER diagram embedded in AquaChem V.4. ${ }^{\circledR}$. This was also used to classify "hydrochemical facies" or "water types" based on the dominant ions (Piper 1944). Gibb's and Chadha's diagrams were used to assess major water evolutions/ mechanisms, relationships between water chemistry and aquifer lithology, and to differentiate contributions of rock-water interactions, ET and precipitation dominances (Gibbs 1970; Chadha 1999). Ion exchange and reverse ion exchange reactions were assessed using Chloro-alkaline indices 1 and 2 (CAI 1 and CAI 2, Eqs. 6 and 7), all conc.

\begin{tabular}{lll}
\hline Indices & Formulae & References \\
\hline Sodium absorption ratio (SAR) & $\mathrm{SAR}=\frac{\mathrm{Na}}{\sqrt{(\mathrm{Ca}+\mathrm{Mg}) / 2}}(2)$ & Inayathulla and Paul (2013); Sadashivaiah et al. (2008) \\
Residual sodium carbonate (RSC) & $\mathrm{RCS}=\left(\mathrm{HCO}_{3}+\mathrm{CO}_{3}\right)-(\mathrm{Ca}+\mathrm{Mg})(3)$ & $\begin{array}{l}\text { Inayathulla and Paul (2013); } \\
\text { Kaur and Singh (2011) } \\
\text { Percent sodium (\%Na) }\end{array}$ \\
$\begin{array}{ll}\text { Kelly's ratio (KR) } \\
\end{array}$ & $\mathrm{KR}=\frac{\mathrm{Na}}{(\mathrm{Ca}+\mathrm{Mg})}(5)$ & $\begin{array}{l}\text { Sadashivaiah et al. (2008); } \\
\text { Kaur and Singh (2011) }\end{array}$ \\
& & $\begin{array}{l}\text { Inayathulla and Paul (2013); } \\
\text { Kaur and Singh (2011) }\end{array}$ \\
\hline
\end{tabular}




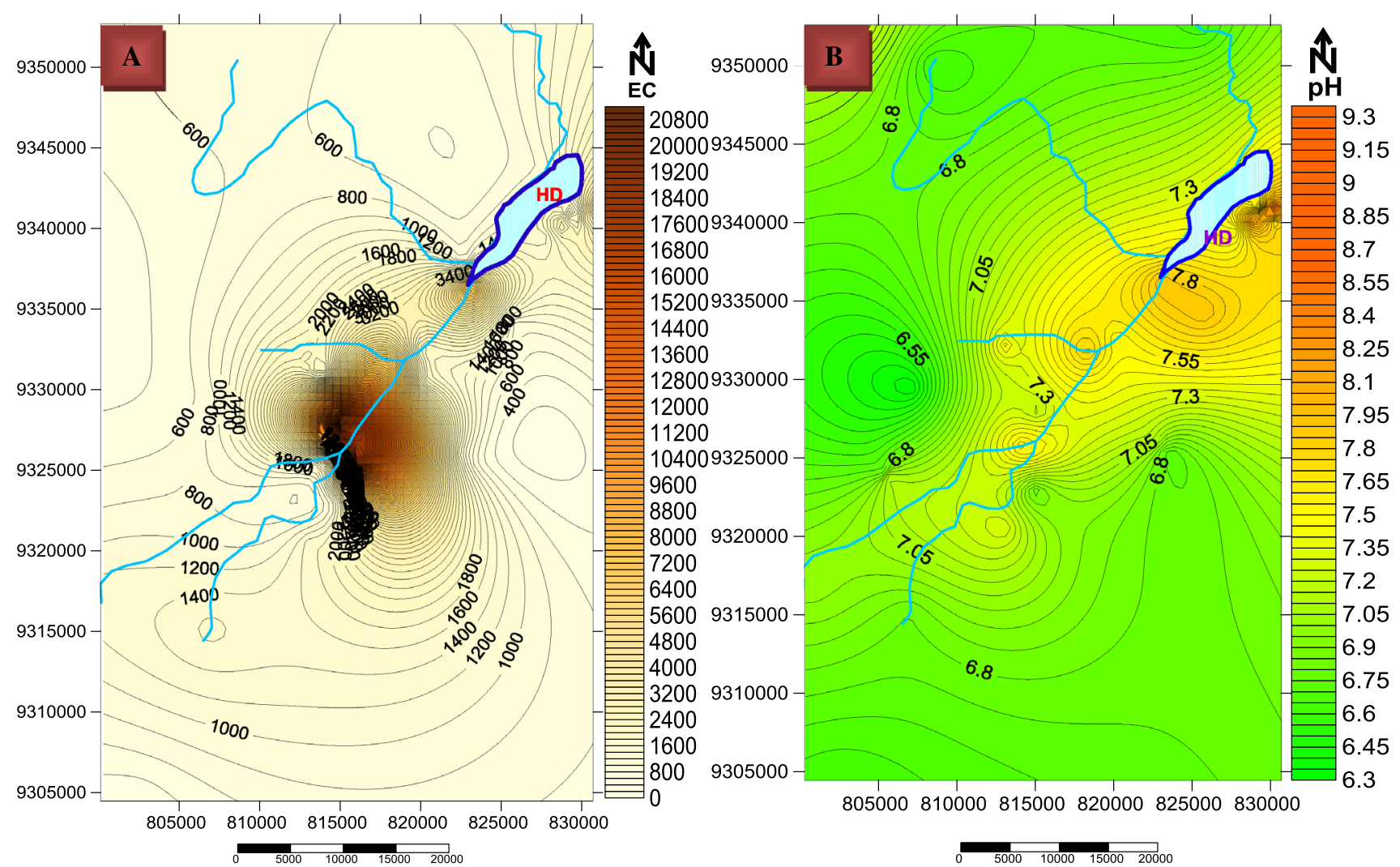

Fig. 2 a Spatial EC distribution, b Spatial $\mathrm{pH}$ distribution from the study catchment

expressed in meq/L. Field observations (FOs) and Focus group discussions (FGDs) were held for five (5) months covering both the dry season (September-October 2013) and wet season (December, 2013 - February, 2014). When the use of local Gogo dialect was necessary, due to communication barriers, the field assistant (Mr. Malima) provided translations. Human and geological processes and activities upstream of HD were assessed by analyzing and documenting all potential sources of HD salinity. An extensive literature review was also undertaken.

$$
\begin{aligned}
\mathrm{CAI} 1= & \mathrm{C} 1-\mathrm{Na}+\mathrm{K} / \mathrm{Cl} \\
\mathrm{CAI} 2= & \mathrm{C} 1-\mathrm{Na}+\mathrm{K} / \mathrm{SO}_{4}+\mathrm{HCO}_{3}+\mathrm{CO}_{3} \\
& +\mathrm{NO}_{3}
\end{aligned}
$$

Total hardness (TH) is vital for assessing suitability of water sources for domestic, agricultural and industrial uses and it was assessed using Eq. 8, all concentrations were expressed in ppm. Generally, water sources with TH values of (0-75), (>75-150) (>150-300) (>300) were classified as soft, moderately hard, hard, and very hard, respectively (Kaka et al. 2011).

$\mathrm{TH}=2.497 \times\left[\mathrm{Ca}^{2+}\right]+4.115 \times\left[\mathrm{Mg}^{2+}\right]$

\section{Results}

\section{Physical and hydrogeochemical parameters}

Table 1 summarizes water samples analytical results (range, mean, median and SD values) for major physicochemical water quality parameters. The mean cations and anions followed $\left(\mathrm{Na}^{+}>\mathrm{Mg}^{2+}>\mathrm{Ca}^{2+}>\mathrm{K}^{+}\right)$and $\left(\mathrm{Cl}^{-}>\mathrm{HCO}_{3}{ }^{-}>\mathrm{SO}_{4}{ }^{2-}>\mathrm{NO}_{3}{ }^{-}\right)$order and constituted $(14.34,5.19,4.69,0.40)$ and $(11.83,6.33,3.24,1.13) \mathrm{meq} /$ L, respectively (Table 1). Mean $\mathrm{pH}, \mathrm{EC}$, TDS, TH, SAR, $\% \mathrm{Na}, \mathrm{RSC}$ and $\mathrm{KR}$ were $7.4,3127.8 \mu \mathrm{Scm}^{-1}, 2004.5$, $533.1 \mathrm{ppm}, 6.6,51 \%,-3.5$ and 1.7 , respectively (Tables 1 , 2). The highest total cations (TC) and total anions (TA) occur in the NaCl-rich lithological unit where table salt is mined (Table 1, Plate 1). HD water quality varied with seasons where $\mathrm{pH}$ and EC were slightly lower during the wet season than in the dry season, (8.0 and 8.5) and (3298 and $4006 \mu \mathrm{Scm}^{-1}$ ), respectively (Table 1). The middle of the catchment had highest EC (Fig. 2a).

From Table 1, SD for $\mathrm{Na}^{+}$and $\mathrm{K}^{+}$were 15.19 and 0.46 and ranged from 2.04 to 65.10 and 0.06 to $2.27 \mathrm{meq} / \mathrm{L}$, respectively. SD of $\mathrm{Ca}^{2+}$ and $\mathrm{Mg}^{2+}$ were 2.81 and 3.85 and 


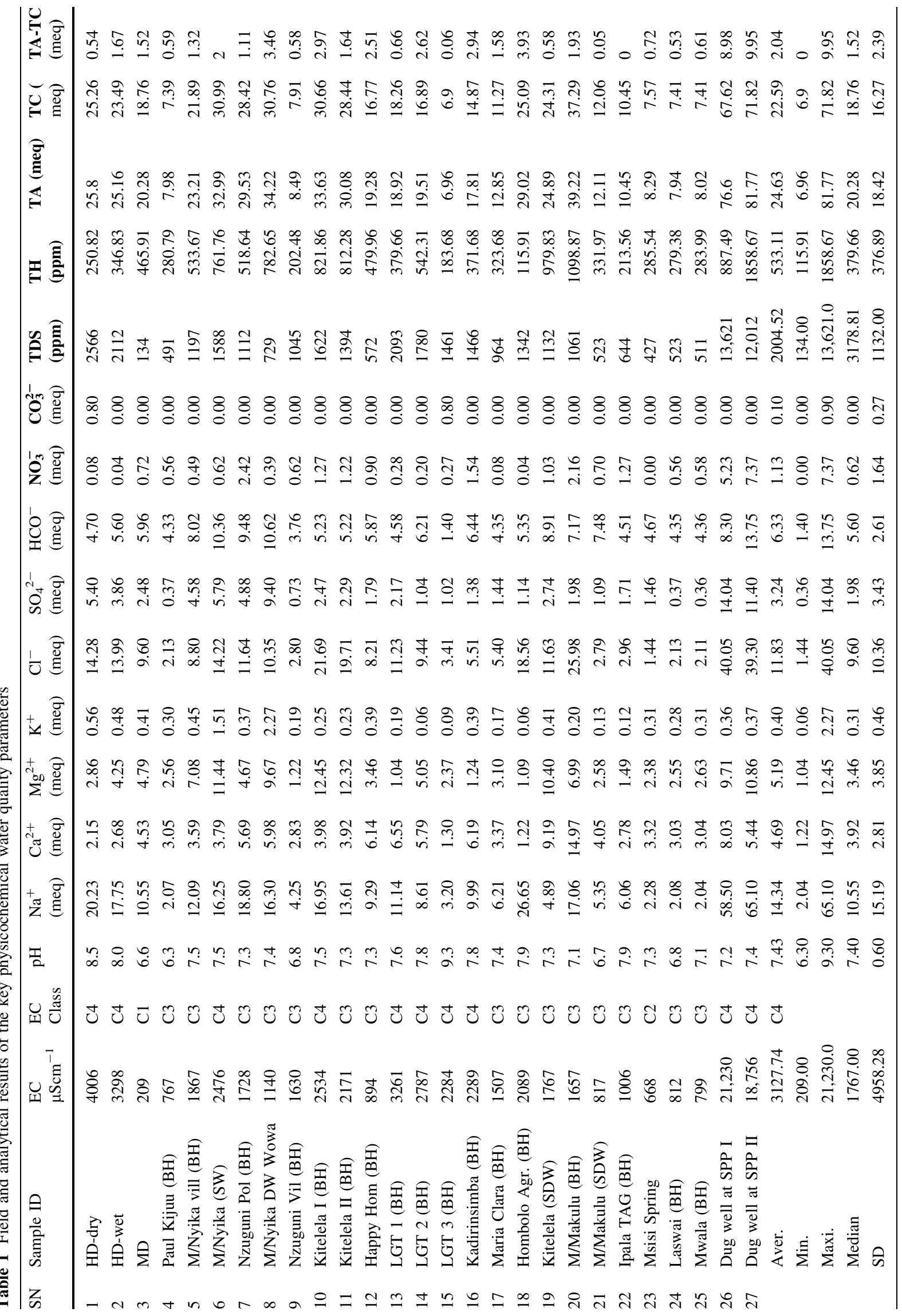




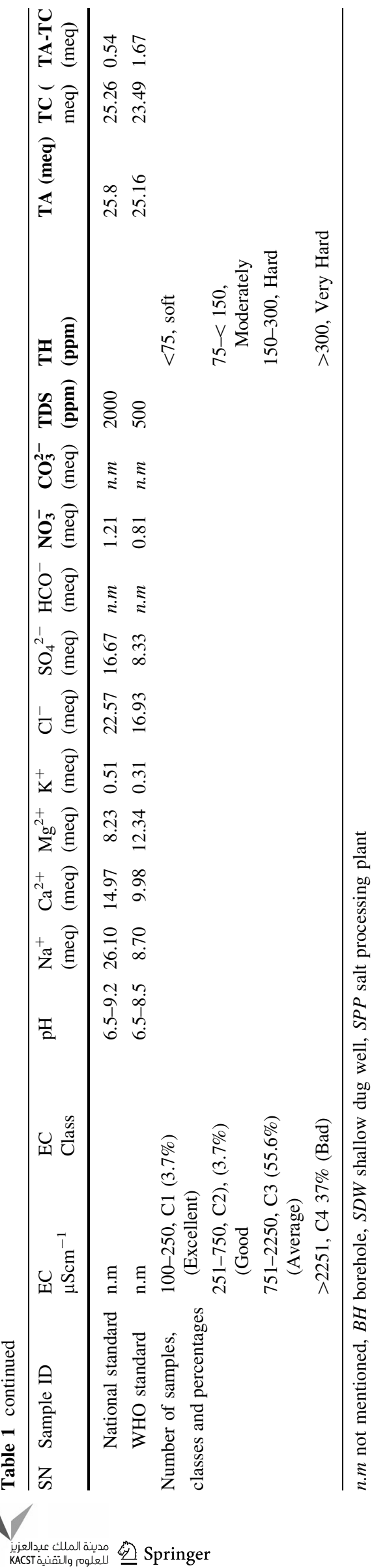

ranged from (1.22 to 14.97$)$ and 1.04 to $12.45 \mathrm{meq} / \mathrm{L}$, respectively (Table 1 ). $\mathrm{SO}_{4}{ }^{2-}$ ranged from 0.36 to 14.04 and had SD of $3.43 \mathrm{meq} / \mathrm{L}$ (Table 1 ). $\mathrm{Cl}^{-}$ranged from 1.44 to 40.05 and had SD of 10.36 while $\mathrm{NO}_{3}{ }^{-}$ranged from 0.0 to 7.37 and had SD of $1.64 \mathrm{meq} / \mathrm{L}$, respectively (Table 1). The highest $\mathrm{NO}_{3}{ }^{-}$and $\mathrm{Cl}^{-}$were recorded at the two SDWs within the limestone and salt materials and processing activities (LSPMA) (Table 1). Mostly nil to traces of $\mathrm{CO}_{3}{ }^{2-}(0-0.8 \mathrm{meq} / \mathrm{L})$ were recorded in most waters while $\mathrm{HCO}_{3}{ }^{-}$was the dominant anion varying from 1.4 to 13.75 with SD of $2.61 \mathrm{meq} / \mathrm{L}$ (Table 1).

Table 1 shows that $29.6 \%$ of samples were above the national and WHO PL for $\mathrm{NO}_{3}{ }^{-}$. While all samples were within national $\mathrm{PL}$ for $\mathrm{SO}_{4}{ }^{2-}, 11.1 \%$ were above the WHO PL. With regards to $\mathrm{Cl}^{-}, 22.2$ and $11.1 \%$ of the samples were above the PL for WHO and national standards, respectively. In terms of cations, $3.7 \%$ of the samples were above $\mathrm{Ca}^{2+} \mathrm{PL}$ for both WHO and national PL while 3.7 and $22.2 \%$ were above the WHO and national PL for $\mathrm{Mg}^{2+}$, respectively. Furthermore, 48.1 and $11.1 \%$ of samples were above WHO and national $\mathrm{PL}$ for $\mathrm{K}^{+}$, respectively. 72.7 and $11.1 \%$ of samples were above the WHO and national PL for $\mathrm{Na}^{+}$, respectively which represent a big difference between the two guidelines. Finally, 66.7, 29.3, and $3.7 \%$ of samples had very hard; hard and moderately hard $\mathrm{TH}$ values, respectively and had a mean value of 533.1 and a range of 115.91-1858.7 (Table 1). This survey indicated that prior to this study no water quality assessment existed for about $63 \%$ of the samples and that local people mostly used water of unknown quality (Field observations s and FGDs).

\section{Major mechanisms controlling water quality, evolution and hydrogeochemical facies}

Figure 4 shows that most water samples were in rock dominance. However, for both wet and dry seasons, HD and samples collected from shallow groundwater $(\mathrm{SG})$ in the LSPMA were in the ET dominance. Unlike HD, MD spanned in the rock dominance, and closer to precipitation and had the least TDS abundance. Notice that no samples were in the precipitation dominance and that most samples had high TDS and occurred in the upper half of Gibbs plots (Fig. 4). The order of water chemical mechanism dominance was seawater ET, reverse ion exchange, recharge water and to a limited extent, ion exchange, respectively (Fig. 3b). Figure 7 shows that the dominant cations and anions were $\left(\mathrm{Na}^{+}+\mathrm{K}^{+}\right)$and $\mathrm{Cl}^{-}$, respectively and the major water type was $\mathrm{Na}-\mathrm{Cl}$ followed by mixed $\mathrm{CaMgCl}$ and $\mathrm{CaHCO}_{3}$ in that order. For both seasons, HD and SGs from the LSPMA had $\mathrm{Na}-\mathrm{Cl}$ water type while $\mathrm{MD}$ was represented by $\mathrm{CaHCO}_{3}$ and seasonal 
Table 2 Major statistics for SAR, \%Na, RSC, KR and Indices

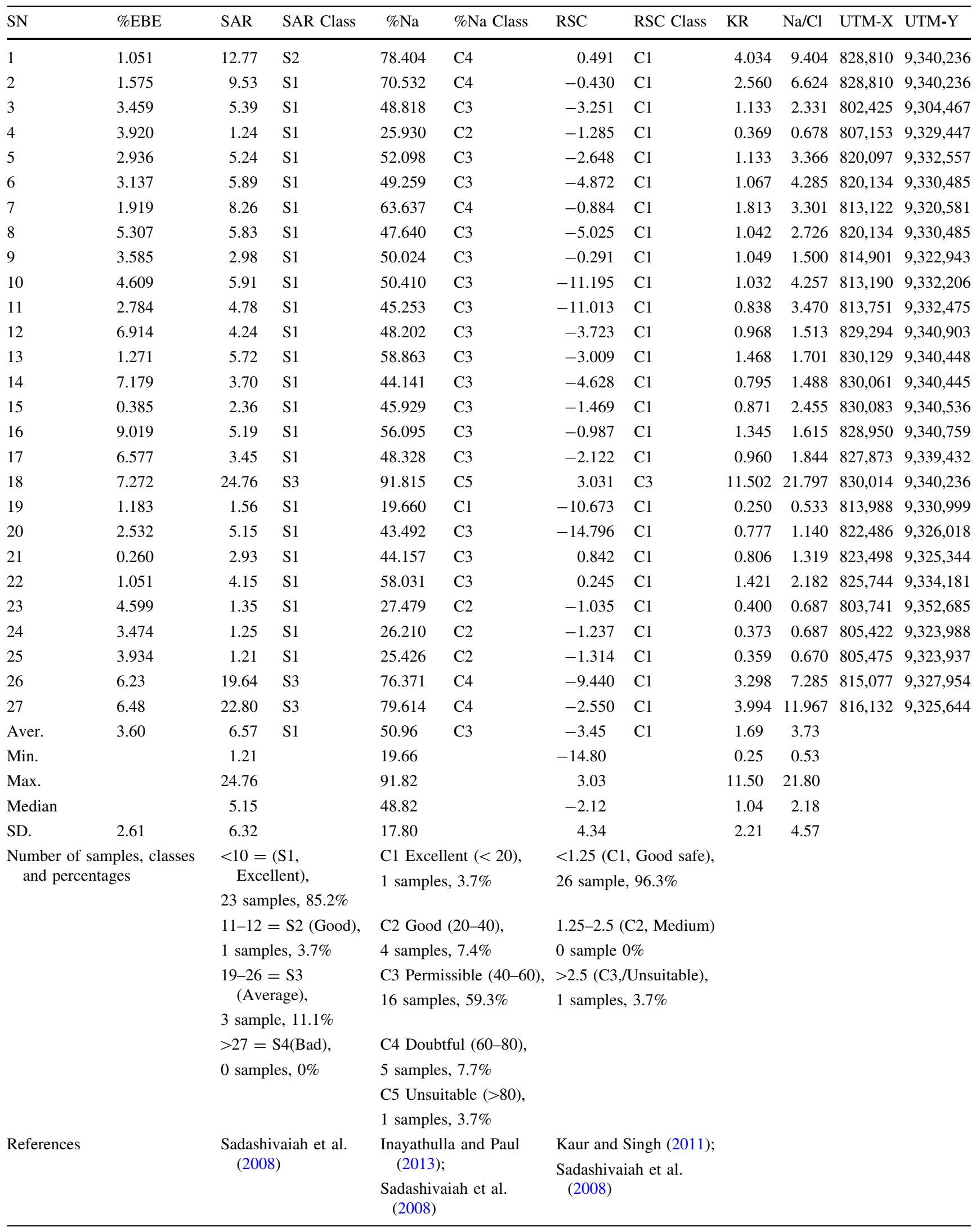


A

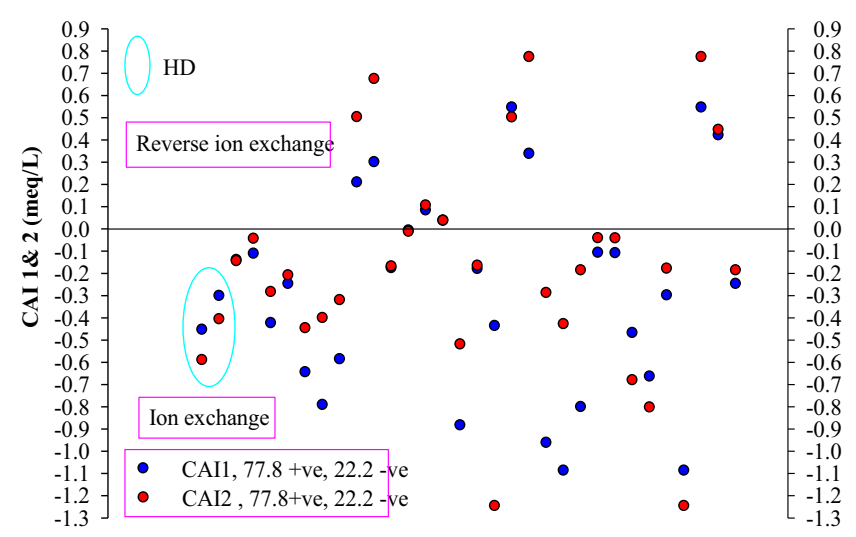

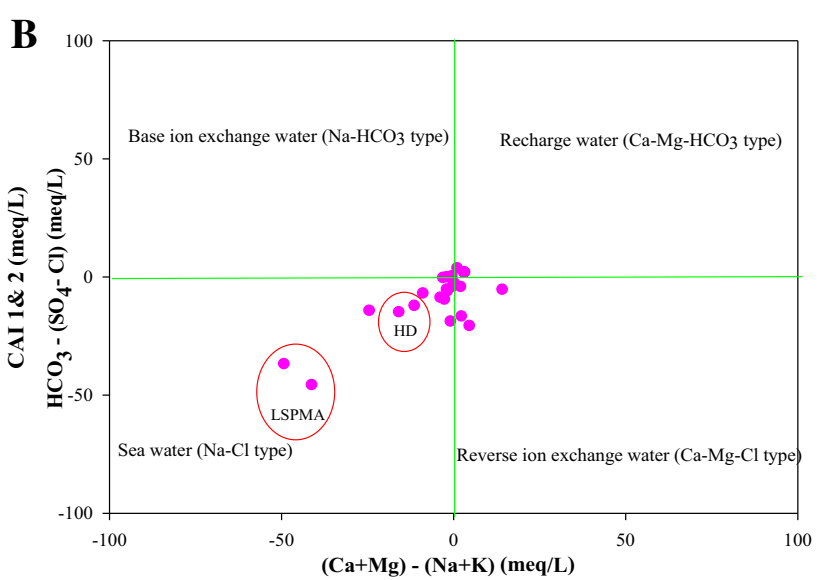

Fig. 3 a CAI 1 and CAI 2, b Chadha diagrams for hydrogeochemical facies and evolutions

dilution did not change the general chemistry (Fig. 7a). While one sample had mixed $\mathrm{CaNaHCO}_{3}$, none had $\mathrm{CaCl}$ and $\mathrm{NaHCO}_{3}$ types.

Figure $5 \mathrm{a}$ shows that the molar ratio between $\mathrm{Na} / \mathrm{Cl}$ were mostly $>1$ and plotted below the (equiline 1:1). Figure $6 \mathrm{~d}, \mathrm{p}, \mathrm{j}$ show that most samples span above equilines of $\mathrm{HCO}_{3}{ }^{-}$vs. $\left(\mathrm{Na}^{+}+\mathrm{K}^{+}\right),\left(\mathrm{Ca}^{2+}+\mathrm{Mg}^{2+}\right)$ vs. $\left(\mathrm{HCO}_{3}{ }^{-}+\mathrm{SO}_{4}{ }^{2-}\right)$ and $\left(\mathrm{Ca}^{2+}+\mathrm{Mg}^{2+}\right)$ vs. TC, respectively. Further, most samples were below and above $\left(\mathrm{HCO}_{3}{ }^{-}+\mathrm{SO}_{4}{ }^{2-}\right)$ vs. $\left(\mathrm{Na}^{+}+\mathrm{K}^{+}\right)$and $\left(\mathrm{Ca}^{2+}+\mathrm{Mg}^{2+}\right)$ vs. $\mathrm{HCO}_{3}^{-}$equilines, respectively. Notice the strong - ve correlation $\left(r^{2}=0.73\right)$ between $\left(\mathrm{Ca}^{2+}+\mathrm{Mg}^{2+}\right)-\left(\mathrm{HCO}_{3}{ }^{-}+\mathrm{SO}_{4}{ }^{2-}\right)$ vs. $\left(\mathrm{Na}^{+}\right.$to $\left.\mathrm{Cl}^{-}\right)$ (Fig. 6f) and high +ve correlations between $\left(\mathrm{Na}^{+}+\mathrm{K}^{+}\right)$ vs. $\left(\mathrm{Cl}^{-}+\mathrm{SO}_{4}{ }^{2-}\right),\left(\mathrm{Na}^{+}+\mathrm{K}^{+}\right)$vs. TC and $\left(\mathrm{Ca}^{2+}+-\right.$ $\mathrm{Mg}^{2+}$ ) vs. TC of (Fig. 6i, $r^{2}=0.9$ ), (Fig. $6 \mathrm{~m}, r^{2}=0.93$ ) and (Fig. $6 \mathrm{j}, r^{2}=0.9$ ), respectively. Notice also the $+\mathrm{ve}$ correlation $\left(r^{2}=0.56\right)$ between $\mathrm{Cl}^{-}$and $\mathrm{NO}_{3}{ }^{-}$and that the highest values were recorded at the SG within the LSPMA (Table 1). A plot of $\mathrm{Cl}$ vs. TA and $\left(\mathrm{HCO}_{3}{ }^{-}+\mathrm{SO}_{4}{ }^{2-}\right)$ vs. TA revealed that all samples plotted below the equiline, Fig. 5r, t, respectively. Further, $81.5 \%$ of samples in a graph of $\left(\mathrm{Ca}^{2+}+\mathrm{Mg}^{2+}\right)$ vs. $\mathrm{Cl}^{-}$plot above the equiline and that $\left(\mathrm{Ca}^{2+}+\mathrm{Mg}^{2+}\right)$ increases with salinity (Fig. $5 b$ ). Further, $\mathrm{Na} / \mathrm{Cl}$ slightly decreases with $\mathrm{Cl}^{-}$(Fig. 6s). The $\mathrm{Na} / \mathrm{Ca}$ molar ratio of about $52 \%$ of the samples locally were $>2$ with mean and range of 3.73 and $0.53-21.8$, respectively (Table 2). Figure 3 a shows that most samples (including HD) had -ve CAI 1 and CAI 2 values (70.4\%) while a few had + ve values (29.6\%) and were located in the ion exchange and reverse ion exchange, respectively. Finally, Fig. $7 \mathrm{~b}$ shows the Schoeller diagram which, irrespective of various concentrations from different samples, similar patterns could be traced.

\section{Irrigation water suitability indices}

Table 2 shows that from different indices, local water suitability for irrigation is highly variable. While water with KR of $<1$ is suitable for irrigation, current results show that $55.6 \%$ of samples had KR of $>1$ with HD and samples from LSPMA having KR of $>2$ and $>3$, respectively. Based on the SAR index, $85.2 \%$ of samples were grouped as $\mathrm{S} 1$ while 3.7 and $11.1 \%$ had $\mathrm{S} 2$ and $\mathrm{S} 3$, respectively. By following \% Na index, 3.7, 7.4, 59.3, 7.7 and $3.7 \%$ of the samples were classified as $\mathrm{C} 1, \mathrm{C} 2, \mathrm{C} 3, \mathrm{C} 4$ and C5, respectively (Table 2). Based on RSC classification, $96.3 \%$ of the samples were good for irrigation whilst $3.7 \%$ were bad/unusable (Table 2). Notice that based on $\% \mathrm{Na}$ and RSC indices, HD water was suitable and unsuitable for irrigation, respectively (Table 2). From most indices, SN 18 and HD were the most unfit for irrigation while MD and Msisi Spring were the best.

Furthermore, SD for EC and $\mathrm{pH}$ were 4958.3 and 0.60 and ranged from (209 to 21,230$) \mu \mathrm{Scm}^{-1}$ and (6.30 to 9.30 ), respectively. These ranges represent major variations and suggest that most samples were slightly alkaline and saline (Table 1, Fig. 4). Figure 2a, b show the spatial distribution of $\mathrm{pH}$ and EC values. The highest EC occurs around Kitelela and Mahoma Nyika, (at the NaCl-rich lithological unit, which are in the middle of the catchment) whilst the lowest value was recorded around Msisi Spring.

\section{Local water suitability for grape irrigation based on $\mathrm{EC}, \mathrm{Na}^{+}, \mathrm{pH}$, and $\mathrm{Cl}^{-}$parameters}

The results showed that $14.8 \%$ of the samples, including $\mathrm{HD}$ for the dry season were above the $\mathrm{Na}^{+}$PL for grapes irrigation of about $20.01 \mathrm{meq} / \mathrm{L}$. With regard to EC and $\mathrm{Cl}^{-}$parameters, 26 and 29.6, 63 and 48.1, 22.2 and 18.5\% 

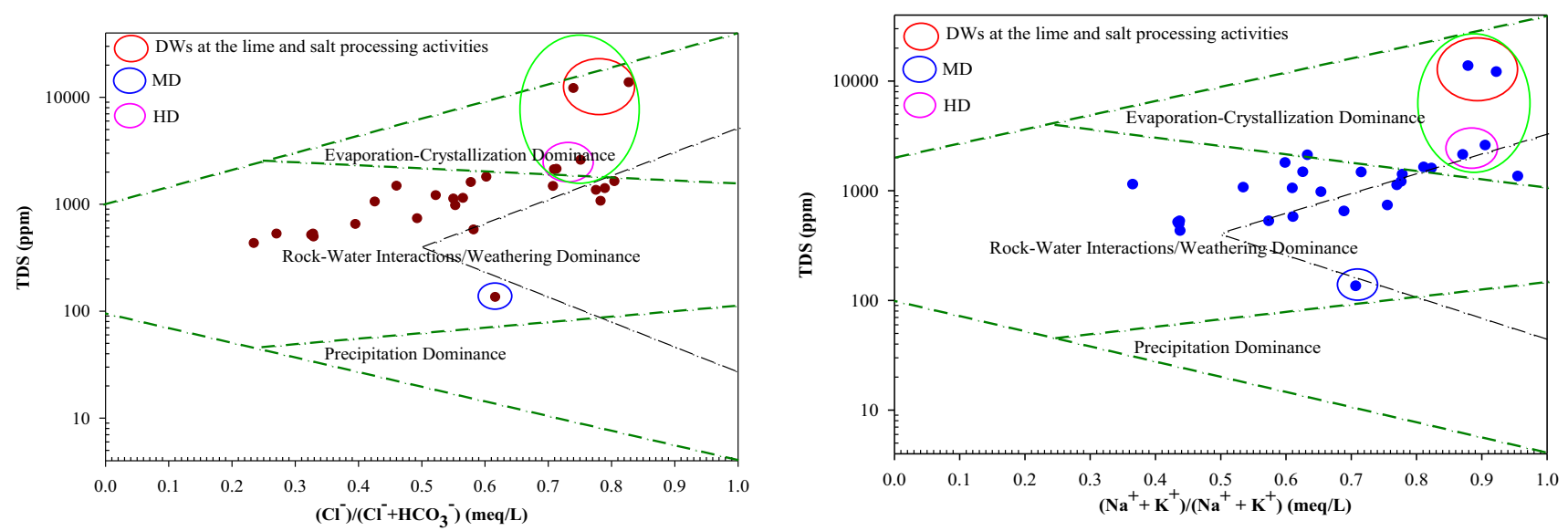

Fig. 4 The major mechanisms controlling the quality of water based on Gibbs (1970)

of the sample would pose none, moderate and severe harm to grape vine, respectively. By using $\mathrm{pH}$ parameter, the results show that $96.3 \%$ of all study waters could be used for grape vine irrigation (Table 1) while one sample, SN 15 had $\mathrm{pH}$ of 9.3 (unsuitable).

\section{Catchment characteristics, human activities and surface hydrology}

This survey revealed highly concentrated NaCl-rich lithological materials and limestone rocks that were used to manufacture table salt and lime powder, respectively (Field observations, Plates 1 and 2). A clear layer of $\mathrm{NaCl}$-rich materials was located about 5-7 km upstream of the dam and along the prominent floodplain of LKR that drains to HD via LKR (Fig. 1, Plate 1). These activities heavily use fuelwood, which has resulted to severe catchment destruction (Plates 1 and 2). It is worth noting that these materials are not mapped in the existing geological map (Fig. 1).

This study revealed that the catchment had undergone severe destruction/degradation, due to deforestation, uncontrolled SDWs developments and runoff diversions to SDWs and crop field. There are severe fuelwood shortages due to unregulated vegetation clearances for charcoal/fuelwood (Plates 1 and 2). 'Getting enough fuelwood at my age is the most challenging part of the salt making process. Recently, we are mostly using crop residues, animal droppings, leaves and grasses or buy fuelwood which, reduces profit margins (Personal communication with Bibi Ekisa Nkazumwa of Nzuguni suburb).

The SDWs were in the runoff channels of HD and are designed to improve well storage and dilute the high water salinity. Field observations showed that the area often floods during heavy rains and when the water recedes to $\mathrm{HD}$, due to irrigation and ET, the concentrated salty water flows with it to the dam.

\section{Discussions}

\section{Major mechanism controlling water quality and hydrochemical facies}

The major mechanisms controlling compositions and sources of dissolved ions in local water sources are presented by Gibbs and Chadha plots (Figs. 3b, 4). Gibbs plot shows that most samples span in water-rock dominance while a few trended towards ET with none occurring in the precipitation dominance (Fig. 4). Thus, rock-water interactions leading to weathering of the rock forming minerals (ion exchange and reverse ion exchange) were mostly accountable for the main water chemical species. Hence, local geology plays key roles on hydrogeochemistry and water genesis and suggests interactions between the chemistry of rock and that of percolating waters under the subsurface.

This agrees with previous findings that local groundwater dated thousands of years (URT 2002). However, HD for both seasons plotted in ET dominance and closer to SG from the LSPMA (Fig. 4). The co-existence of HD with SG samples suggests common hydrogeochemical mechanisms and is crucial in understanding the dam's water quality. Worth stressing, although HD plotted in the ET dominance, it does not necessarily imply its hydrochemistry is due to high dam surface ET. The SG from the NaCl-rich lithological unit was equally influenced by ET suggesting that the water type was not exclusive to HD (Fig. 4). The dam also receives water from the groundwater (Shindo 1991) hence its chemistry is also likely influenced by the aquifer properties with the SG at the LSPMA, which was ET dominated, probably making a crucial contribution.

The trending of some samples towards ET was expected for such a semi-arid area with high ET (about $2000 \mathrm{~mm} /$ yr.) against low rains (about $550 \mathrm{~mm} / \mathrm{yr}$.). Thus, local dryness, semi-aridity and high ET play vital roles in the 

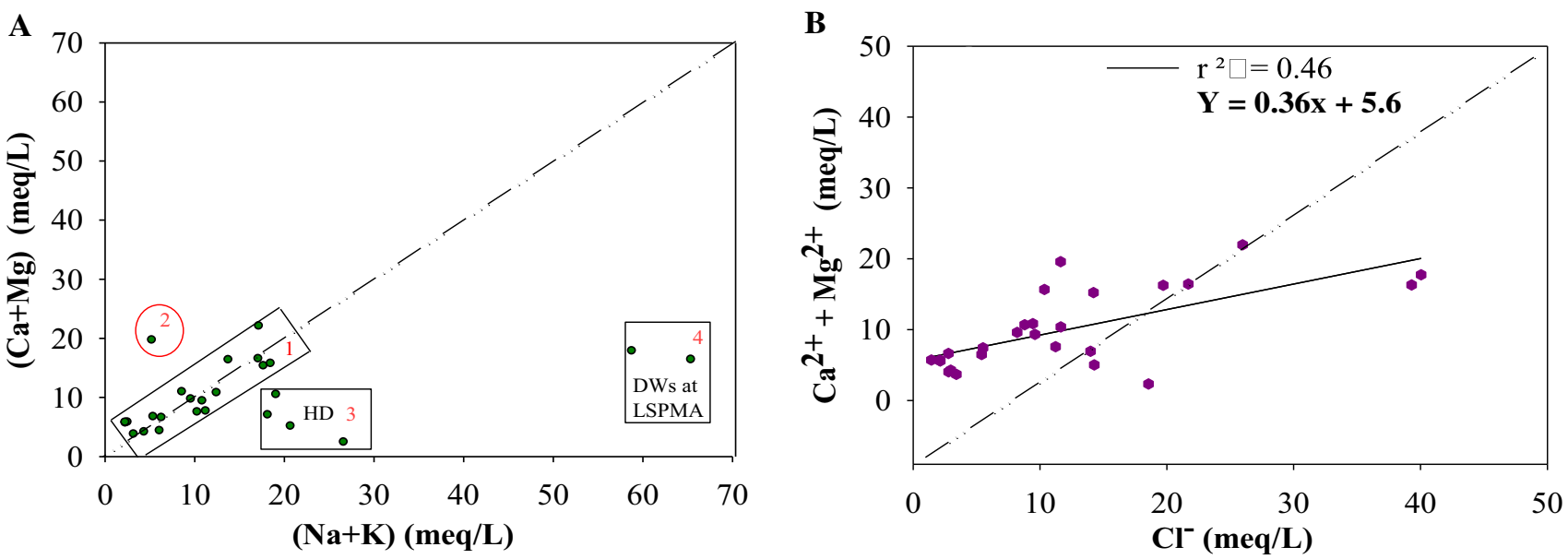

Fig. 5 a A plot of $\left(\mathrm{Na}^{+}+\mathrm{K}^{+}\right)$vs. $\left(\mathrm{Ca}^{2+}+\mathrm{Mg}^{2+}\right)$, b A Plot of $\left(\mathrm{Na}^{+}+\mathrm{K}^{+}\right)$vs. $\mathrm{Cl}$

local water chemistry and its management. A study in India also showed that ET led to increased chemical budget of groundwater (Kumar 2013).

Unlike HD, MD occurred in rock dominance and closer to precipitation (Fig. 4). These findings offer a sharp contrast between the two dams sitting in similar environmental settings and further challenges the notion that high HD surface ET was the only/main factor for its high salinity as suggested by Shindo (1991).

To further explore water chemistry mechanisms, a modification of piper plot after Chadha (1999) showed that most samples plotted in the seawater including samples from HD and SG from the LSPMA area. The next most dominant categories were reverse ion exchange, recharge waters and ion exchange in that order (Fig. 3b). However, Dodoma lies in the inland of the country which rules out the possibility of seawater intrusion. Furthermore, seawater intrusion leads to a plot of $\mathrm{Cl} /$ Anions of $>0.8$ (Zaidi et al. 2015). Locally, all samples had $\mathrm{Cl}^{-} /$Anions of $<0.8$ (Fig. 6r) and seawater intrusion was thus excluded. Thus, the water falling in the seawater can only be attributed to excessive ET (Zaidi et al. 2015). Furthermore, the molar $\mathrm{Na} / \mathrm{Ca}$ ratios of about $52 \%$ of samples were $>2$ (Table 2 ) indicating silicate minerals reactions and/or occurrence of cation exchange (Prasanna et al. 2011). These results reaffirm that multiple processes control local water chemistry and evolution.

The ratio of $\mathrm{Na} / \mathrm{Cl}$ vs. $\mathrm{EC}$ is also used to assess the roles of ET in water genesis and chemistry. The increasing EC with $\mathrm{Na} / \mathrm{Cl}$ ratio remaining unchanged indicates that $\mathrm{ET}$ is a principal process (Prasanna et al. 2011; Zaidi et al. 2015). Locally, this plot shows a slightly +ve slope suggesting multiple processes other than ET influences genesis of local water sources (Zaidi et al. 2015). To confirm this, Gibbs plot showed that most samples occurred in rock dominance while about 5 trended towards ET (Fig. 4).
Furthermore, in a situation dominated by ET, with no mineral species precipitation, a plot of $\mathrm{Na} / \mathrm{Cl}$ results in a horizontal line (Fig. 7a). Otherwise, a ratio of $>1$ is expected when $\mathrm{Na}^{+}$is released from silicate weathering (Prasanna et al. 2011). Locally, most samples had a ratio of $>1$ (Fig. 7a). Higher $\mathrm{Na}^{+}$and $\mathrm{Cl}^{-}$correlation (Fig. 7a) suggests dissolution of chloride salts and/or ET concentration (Jalali 2007). However, the correlation between $\mathrm{Cl}^{-}$ and TA was 0.93 suggesting that most of the alkali ions were balanced by $\mathrm{Cl}^{-}$(Fig. 6r, Zaidi et al. 2015).

Higher conc. of $\mathrm{Cl}^{-}$(aver. of $11.83 \mathrm{meq} / \mathrm{L}$, Table 1) suggests longer water-rock silicate weathering interactions (Jalali 2007). This is supported by a poor correlation between $\mathrm{HCO}_{3}{ }^{-}$and $\mathrm{Cl}^{-}(r=0.32$, Fig. 5O) which suggest dissimilar processes were responsible for occurrence of these two ions (Kaka et al. 2011). In contrast, the graph of $\left(\mathrm{Na}^{+}+\mathrm{K}^{+}\right)$vs. $\left(\mathrm{Cl}^{-}+\mathrm{SO}_{4}{ }^{2-}\right)$ resulted into $r^{2}=90$. A strong $+v e$ correlation (i.e. increase in alkalies $\left(\mathrm{Na}^{+}+\mathrm{K}^{+}\right)$corresponded with an increase in $\left(\mathrm{Cl}^{-}+\right.$$\mathrm{SO}_{4}{ }^{2-}$ ) implies a common source of these ions (Zaidi et al. 2015; Prasanna et al. 2011).

Figure 7a shows that most samples scatter below the equiline which suggests that reverse ion exchange/halite dissolution were the major mechanisms controlling the bulk of local water chemistry. These include samples from HD and SG from the LSPMA area (Fig. 5a). Furthermore, for most samples, $\mathrm{Na}^{+} / \mathrm{Cl}^{-}$was $>1$ suggesting that silicate dissolution/weathering was the most likely source for $\mathrm{Na}^{+}$ according to Eq. 9 while samples having $\mathrm{Na}^{+} / \mathrm{Cl}^{-}<1$ could be from other mechanisms, including pollution (Kumar 2013; Prasanna et al. 2011).

$$
\begin{aligned}
& 2 \mathrm{NaAlSi}_{3} \mathrm{O}_{8}+\underset{2}{2 \mathrm{H}_{2} \mathrm{CO}_{3}}+9 \mathrm{H}_{2} \mathrm{O} \Rightarrow \\
& \mathrm{Al}_{2} \mathrm{Si}_{2} \mathrm{O}_{5}(\mathrm{OH})_{4}+2 \mathrm{Na}^{+}+4 \mathrm{H}_{4} \mathrm{SiO}_{4}+2 \mathrm{HCO}_{3} \\
& \text { (Silicateweathering) } \\
& \text { (Kaolinite) }
\end{aligned}
$$

(Albite) (Silicate weathering) (Kaolinite) 

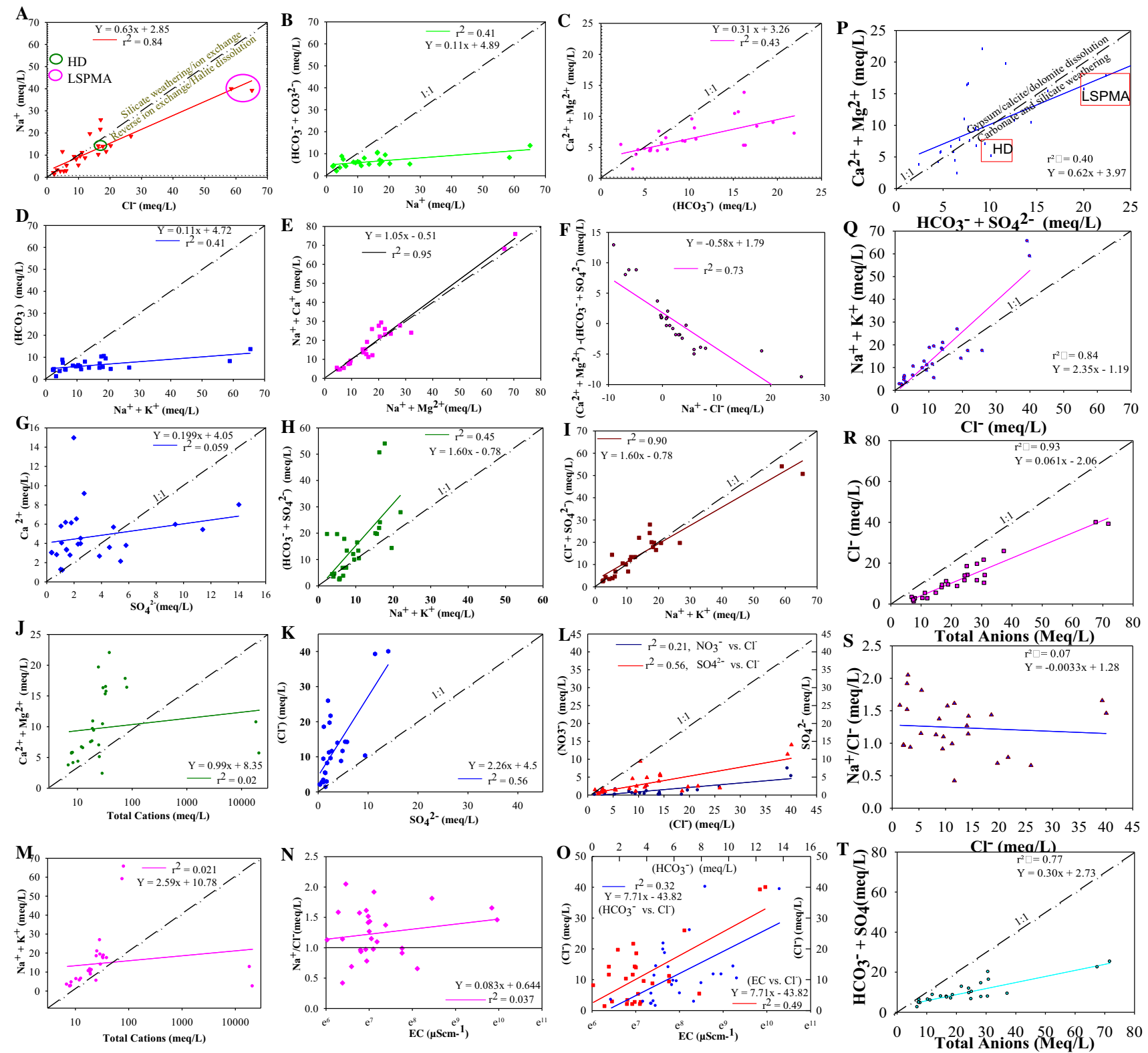

Fig. 6 Ionic relationships and ratios of the major local anions and cations in water sources from Hombolo dam catchment, Tanzania. The dashdotted lines represent equilines $(1: 1)$

However, Fig. 4 showed that HD together with SG from LSPMA area were in ET dominance which suggest that the water- rock influenced water (Fig. 7a) was further concentrated by ET (Fig. 4). Co-influencing of these processes has widely been reported (Prasanna et al. 2011). The fact that most samples plotted below the equiline $(\mathrm{Na}=\mathrm{Cl})$ is an additional confirmation that the excess $\mathrm{Cl}$ comes from additional geochemical processess, mostly ET and pollution (Prasanna et al. 2011).

Figure 61 shows simultaneous co-existence of $\mathrm{NO}_{3}{ }^{-}$ and $\mathrm{Cl}^{-}\left(r^{2}=21\right)$ which reflects pollution (Neill et al. 2004). The area is highly cultivated and LSPMA take place with no sanitation facilities in place (Plates 1 and 2). Free range livestock feeding practices involving huge trails of herds were also common. The main wastewater stabilization ponds (WWSP) in the near upstream of the catchment have a very low efficiency (Mkude and Saria 2014). The effluent of the poorly treated wastewater passes through the study area before entering HD. Thus, part of these ions could be related to pollution pre dominantly from sewage and agricultural activities. Notice that the highest $\mathrm{NO}_{3}{ }^{-}$was recorded in one of the two SDWs within the LSPMA (SN 27 in Table 1). 

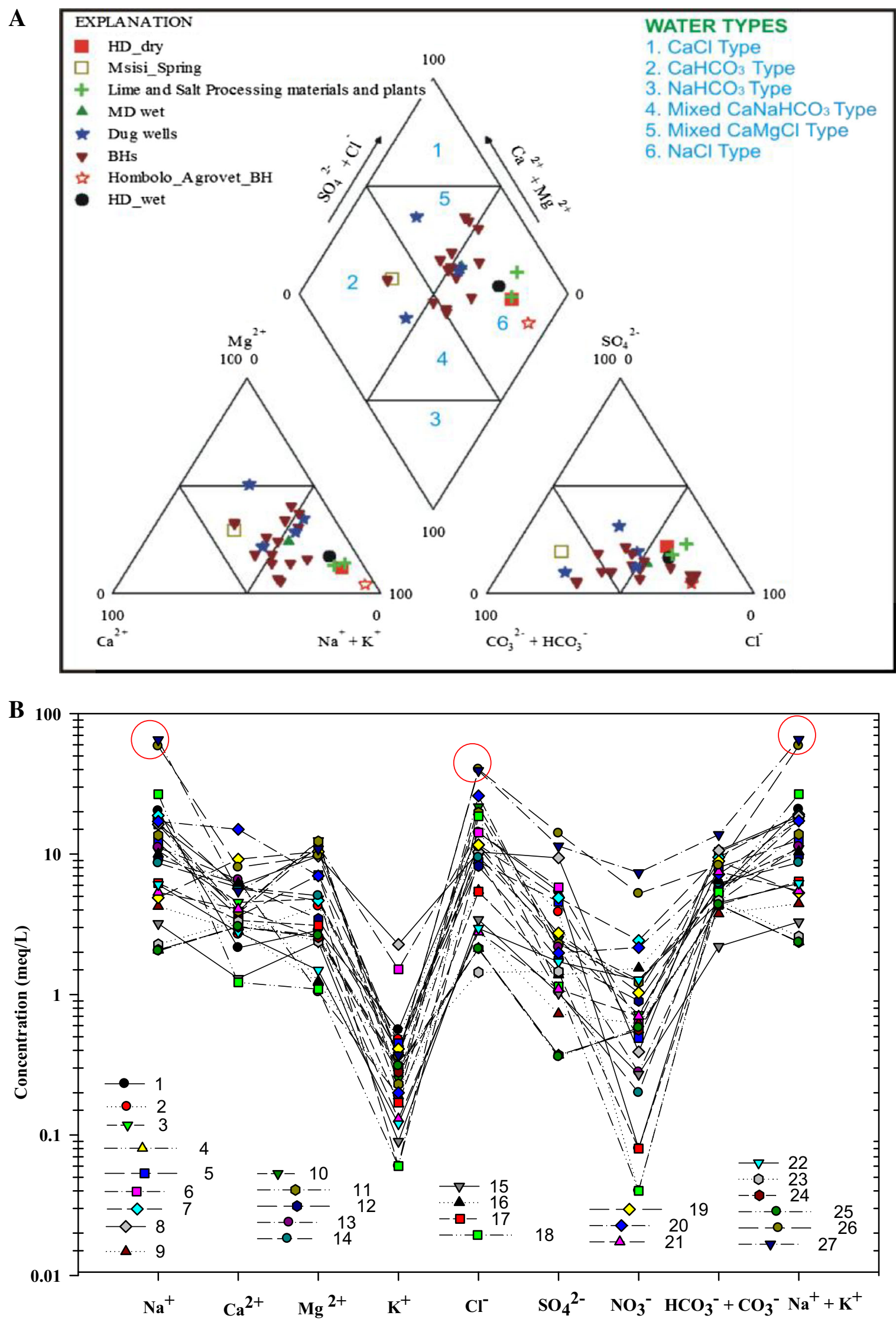

Fig. 7 a Piper Trilinear Diagram, b Schoeller Diagram from the study site 
Although $\mathrm{Na}^{+}$was the most dominant cation, Fig. 3a shows that alkaline earth metals (AEMs) dominated over alkali metals (AMs) and that four classes could be classified. The first class consisted of $74 \%$ and exhibits equal amounts of AEMs and AMs. The second showed a slight abundance of AEMs more than AMs (4\% of samples). The third consists of a slight abundance of AMs making 15\% and included samples from HD. The fourth was marked by an excess of AEM constituted 7\% and included samples from the LSPMA area. The dominance of AEMs over AMs can be attributed to base ion exchange where Groundwater$\mathrm{Na}^{+}$is replaced with $\mathrm{Ca}^{2+}$ and $\mathrm{Mg}^{2+}$ from rock/soil matrices (Fisher and Mullican 1997; Prasanna et al. 2011; Zaidi et al. 2015)

A plot of $\left(\mathrm{Ca}^{2+}+\mathrm{Mg}^{2+}\right)$ vs. $\left(\mathrm{HCO}_{3}{ }^{-}+\mathrm{SO}_{4}{ }^{2-}\right)$ falls close to the equiline when dissolution reactions of calcite, dolomite, and gypsum are dominant in the media. Data falling along the line indicate that the ions mainly originated from weathering of carbonates and sulfate minerals (Prasanna et al. 2011). Locally, about half of the samples plot above the equiline (Fig. 6p.) suggesting that carbonate weathering is the prime source of $\mathrm{Ca}^{2+}$ ions. Samples with values $>1$, suggest an excess of $\left(\mathrm{Ca}^{2+}+\mathrm{Mg}^{2+}\right)$ were derived from a reverse ion exchange (Prasanna et al. 2011). Thus, high $\left(\mathrm{Ca}^{2+}+\mathrm{Mg}^{2+}\right)$ over $\left(\mathrm{SO}_{4}{ }^{2-}+\mathrm{HCO}_{3}{ }^{-}\right)$ strongly suggests a reverse ion exchange (Zaidi et al. 2015). However, the fact that $\left(\mathrm{Ca}^{2+}+\mathrm{Mg}^{2+}\right)$ increased with increasing salinity $\left(\mathrm{Cl}^{-}\right)$(Fig. 4) suggests more reactions other than reverse-ion exchange were occurring in the clay/weathered layer (Prasanna et al. 2011). Ion exchange reactions tend to shift the points to the right of the $1: 1$ line due to the excess supplies of $\left(\mathrm{HCO}_{3}{ }^{-}+-\right.$ $\mathrm{SO}_{4}{ }^{2-}$ ) (Fisher and Mullican 1997). Furthermore, when there is an excess of $\left(\mathrm{Ca}^{2+}+\mathrm{Mg}^{2+}\right)$ than that of $\left(\mathrm{HCO}_{3}{ }^{-}+\mathrm{SO}_{4}{ }^{2-}\right)$ ions, often the points tend to shift to the left side of the 1:1 line owing to reverse ion exchange reactions. To confirm ion exchange reactions were not the sole mechanisms behind the observed water chemistry, a graph of $\left(\mathrm{Ca}+\mathrm{Mg}-\mathrm{SO}_{4}-\mathrm{HCO}_{3}\right)$ vs. $(\mathrm{Na}-\mathrm{Cl})$ was prepared (Fisher and Mullican 1997). Water exhibiting ion exchange plots along a line with a slope of -1 in $\left(\mathrm{Ca}+\mathrm{Mg}-\mathrm{SO}_{4}-\mathrm{HCO}_{3}\right)$ versus $(\mathrm{Na}-\mathrm{Cl})$. Figure $6 \mathrm{~F}$ shows that the slope was about -0.58 suggesting that although ion exchange was taking place, it was not the only factor (Fisher and Mullican 1997). Thus, samples exhibiting reverse ion exchange could be responsible for the
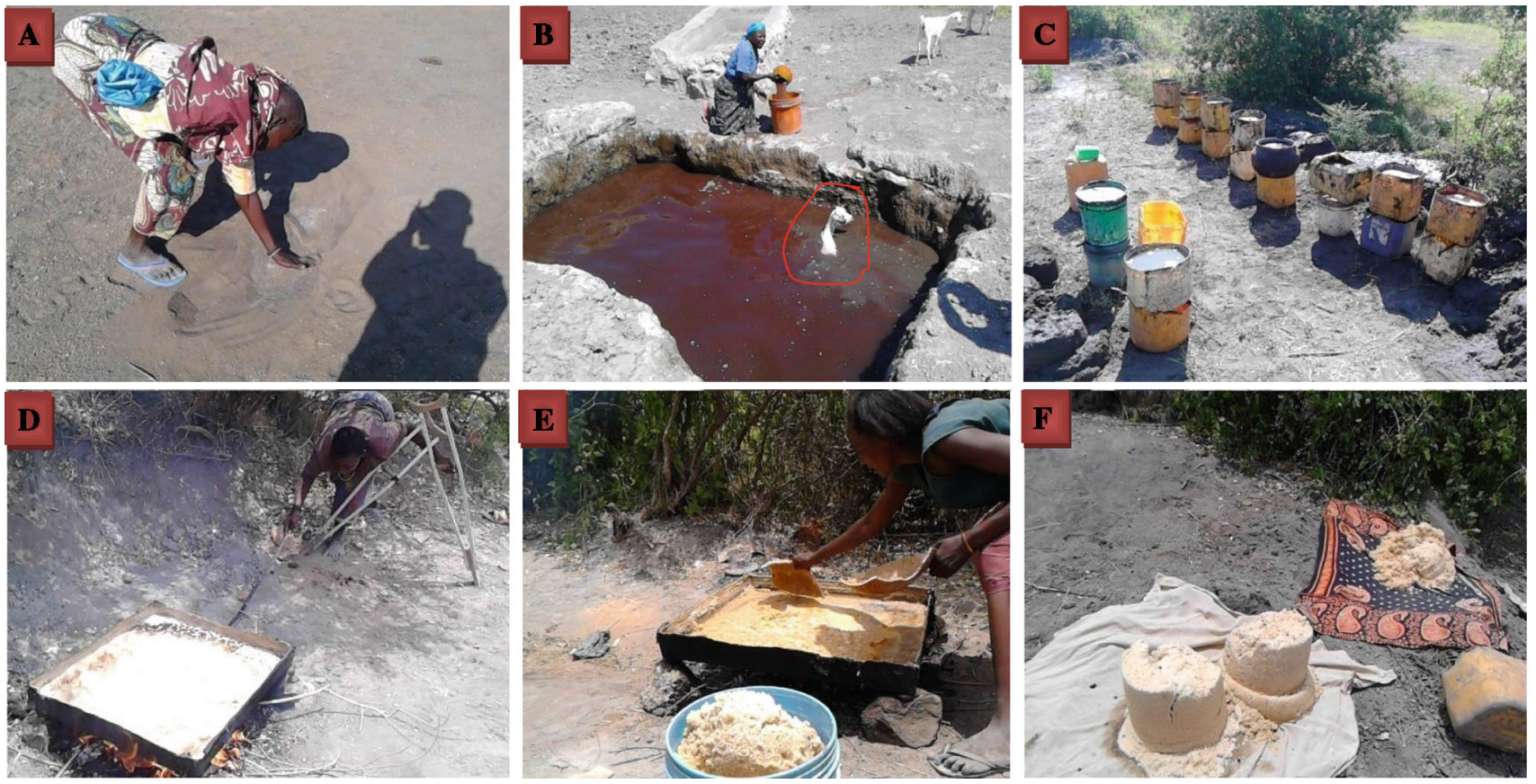

Plate 1 Representation of major processes involved in salt making plants a Removal of top soil in order to collect the inner and more salt concentrated materials at Nzuguni. Notice the whitish salty richer layer just below the top soil. b A lady collecting water from a SDW in Kitelela needed to separate salt from the soil. Notice that a young goat fell into the SDW while attempting to drink water and the dark color of the water that is often contaminated by wastes from huge trails of livestock. The water used to process salt is often of unknown quality. c Local separation of salt done by vigorously stirring soil materials in jerry cans, pouring the mixture in perforated jerry cans packed at the base with fresh leaves to prevent soil particles from escaping the cans but allow filtrates to filter through. d Boiling the filtrates in big pots that expose a large surface area for freshwater to evaporate and leave the salt in the pots. The source of energy could be anything from animal droppings to twigs and poles collected from heavily deforested vegetation. Notice the small size of fuelwood suggesting deforestation of landscape e Removing the salt from the pot after boiling for some $3 \mathrm{~h}$ f Drying salt ready for packaging 

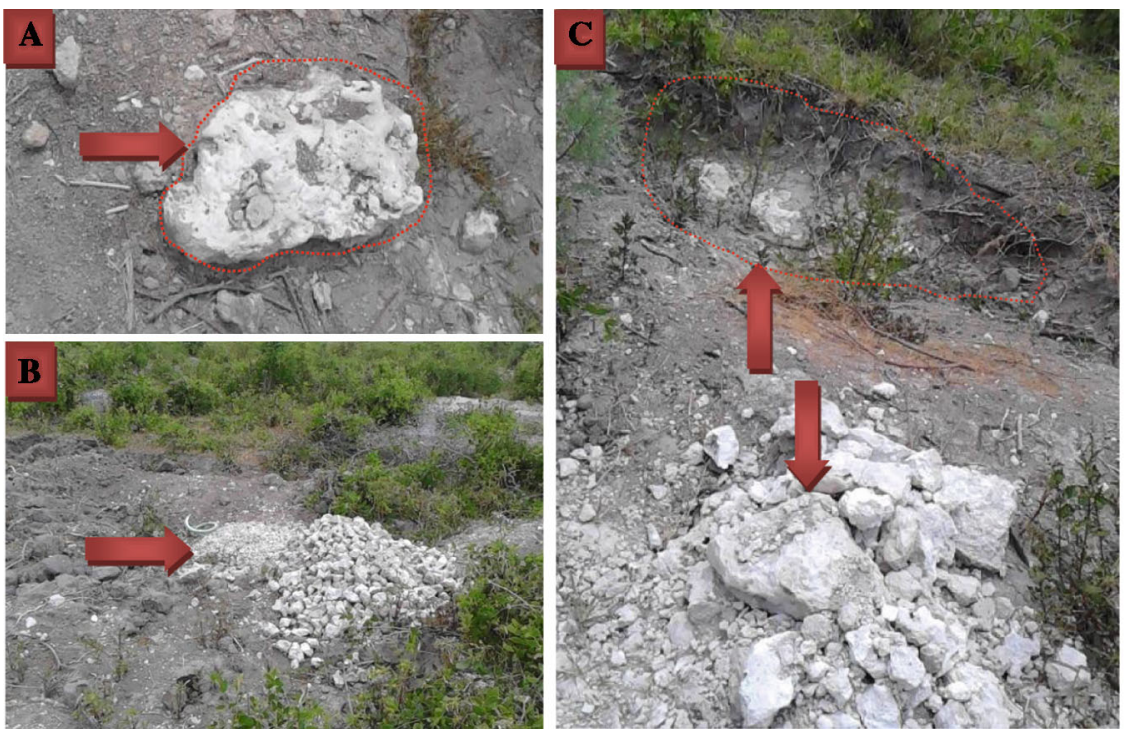
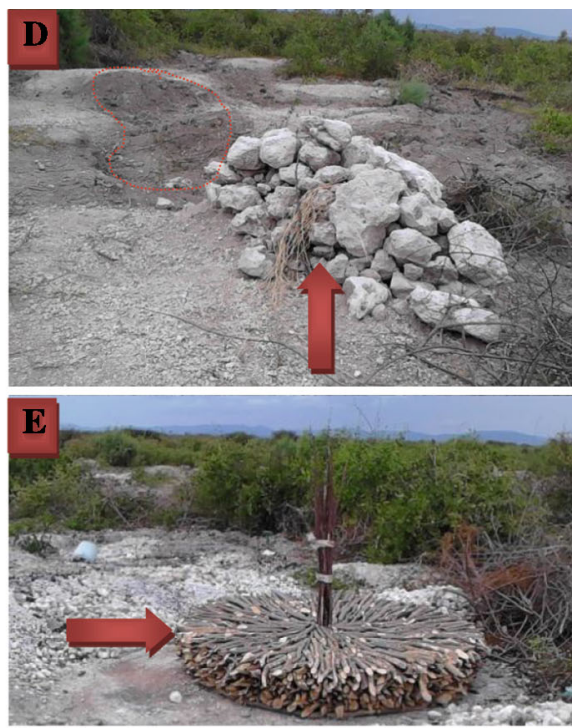

Plate 2 Representation of major processes involved in making lime powder. a Partially exposed limestone rock at Kitelela. These are usually dug to expose the entire rock mass, especially when viewed as of a good quality. b Limestone rock is broken into smaller pieces to increase surface area for burning and breakage. c A scar from where a rock was removed, the lower part of the picture shows initial stages of breaking the rock into smaller pieces. d A pile of rocks dug/collected from the catchment. e An open furnace made of fire-wood. Notice the small sized fire- woods, indicating that large trees in the landscape had been cleared. Improved designs of closed furnaces like the ones

depletion of $\mathrm{Na}^{+}$with respect to $\mathrm{Ca}^{2+}$ and $\mathrm{Mg}^{2+}$ (Zaidi et al. 2015).

Moreover, hydrogeochemical properties and changes along its flow paths can be traced via CAI 1 and CAI 2 indices. Locally, 22.2 and $77.8 \%$ of the samples had +ve and -ve CAI 1 and CAI 2 depicting reverse ion exchange and ion exchanges, respectively (Fig. 3a, b). The + ve ratio shows the likelihood of exchange of $\mathrm{Ca}-\mathrm{Mg}$ (water) by Na-K (mineral) (Eq. 12, Kumar 2013). This further suggests that both reverse ion and ion exchange are common processes. However, local water table, particularly from shallow aquifers are often very high (Shindo 1991) which suggest a likelihood of active exchange of soil/clay $\left(\mathrm{Ca}^{2+}+\mathrm{Mg}^{2+}\right)$ with $\mathrm{Na}^{+}$in groundwater (Eq. 10, 11 and 12); where (exchanged) represents cations exchanged on water or soil/clay.

$\mathrm{Ca}+2 \mathrm{Na}$ (exchanged) $\leftrightarrow 2 \mathrm{Na}^{+}+\mathrm{Ca}$ (exchanged)

$\mathrm{Mg}^{2+}+2 \mathrm{Na}$ (exchanged) $\leftrightarrow 2 \mathrm{Na}^{+}+\mathrm{Mg}$ (exchange)

$\underset{\text { (Water) }}{\mathrm{Na}^{+}+\mathrm{K}^{+}} \underset{\text { Reverse }}{\leftrightarrow} \mathrm{Ca}_{\text {(Rocks) }}^{2+}+\mathrm{Mg}^{2+}$.

The graph of $\left(\mathrm{Ca}^{2+}+\mathrm{Mg}^{2+}\right)$ vs. $\mathrm{HCO}_{3}$ explains the origin of $\mathrm{Ca}^{2+}$ and $\mathrm{Mg}^{2+}$ in groundwater (Prasanna et al. 2011). When $\mathrm{Mg}^{2+}$ and $\mathrm{Ca}^{2+}$ only originate from the used to burn/process mud bricks could save energy as a large part of the heat energy is often lost in the open furnace. Such a furnace is often built into several layers by putting fuel wood as shown in D followed by rock pieces in an alternating manner. The process is done in rings and when done the furnace is set on fire for the limestone pieces to burn. When the rocks have burned for some $3-4 \mathrm{~h}$, water is applied on top of the furnace to break the rocks into powder form. Notice the loose vegetation density in the backgrounds of all pictures suggesting the landscape were severely deforested for fuel wood energy needs

dissolution of carbonates in the aquifer materials and/or weathering of silicate minerals (amphiboles and pyroxenes), this ratio is around 0.5 whereas the ratio of $<0.5$ suggests depletion of $\mathrm{Mg}^{2+}$ and $\mathrm{Ca}^{2+}$ relative to $\mathrm{HCO}_{3}$ due to ion exchange and/or enrichment of $\mathrm{HCO}_{3}{ }^{-}$ (Sami 1992). Locally, 88.9\% of samples, including from HD and the LSPMA had ratios of $>1$ (Fig. 6c). This indicates that carbonate weathering was a key source of high $\mathrm{HCO}_{3}{ }^{-}$. This is supported by the presence of numerous limestone rocks (Plate 2). However, the few values with low ratio $(<0.5)$ suggest $\mathrm{HCO}_{3}{ }^{-}$enrichment and/or $\left(\mathrm{Ca}^{2+}+\mathrm{Mg}^{2+}\right)$ depletion by cation exchange (Fig. 6c). Nonetheless, since $\mathrm{HCO}_{3}{ }^{-}$does not form carbonic acid $\left(\mathrm{H}_{2} \mathrm{CO}_{3}\right)$ under mostly alkaline conditions locally (Table 1), the high ratio was unlikely to be due to $\mathrm{HCO}_{3}{ }^{-}$depletion (Shindo 1991; Prasanna et al. 2011). However, the high ratio could indicate that an excess of alkalinity was balanced by the alkalis metals $\left(\mathrm{Na}^{+}\right.$and $\mathrm{K}^{+}$ ) (Prasanna et al. 2011) or were due to reverse ion exchange (Fig. 3a). Further, the ratio of $<1$ may also indicate existence of fresh recharge (Zaidi et al. 2015). Locally, however, most samples had a high ratio (average 1.59) suggesting limited fresh recharge which is also supported by the low rains $(550 \mathrm{~mm} / \mathrm{yr}$.) and higher ET (about $2000 \mathrm{~mm} / \mathrm{yr}$.) all of which affect net recharge (Shemsanga et al. 2015). Previous studies also indicated 
that the area had low recharge (Shindo 1991, Rwebugisa 2008).

The graph of $\left(\mathrm{Ca}^{2+}+\mathrm{Mg}^{2+}\right)$ vs. TC, showed that $85.2 \%$ of samples were above the equiline indicating a dominant contribution of $\mathrm{Ca}^{2+}+\mathrm{Mg}^{2+}$ in the overall water chemistry (Fig. 6j). This is in line with the results shown in Table 1 that $\mathrm{Ca}^{2+}$ and $\mathrm{Mg}^{2+}$ were the second and third most dominant cations, respectively, and is supported by presence of limestone rocks (Plate 2).

The plots of $\left(\mathrm{Mg}^{2+}+\mathrm{Ca}^{2+}\right) /$ salinity $\left(\mathrm{Cl}^{-}\right)$and $\mathrm{Na} / \mathrm{Cl}$ offer insights on interactions between $\mathrm{Ca}^{2+}, \mathrm{Mg}^{2+}$, and $\mathrm{Na}^{+}$in the groundwater system (Sami 1992). When all Cl is derived from halite dissolution, the increase in $\left(\mathrm{Ca}^{2+}+\mathrm{Mg}^{2+}\right)$ corresponds to increasing $(\mathrm{Cl})$. The plot of $\left(\mathrm{Mg}^{2+}+\mathrm{Ca}^{2+}\right)$ vs. (Cl) showed that $\left(\mathrm{Ca}^{2+}+\mathrm{Mg}^{2+}\right)$ increased with the increasing $\mathrm{Cl}$ (Fig. 5b) whilst $(\mathrm{Na} / \mathrm{Cl})$ ratio slightly decreased with increasing $\mathrm{Cl}^{-}$(Fig. 6s). Thus, the dissolved groundwater $\mathrm{Na}^{+}$(derived from halite dissolution) is exchanged by $\left(\mathrm{Mg}^{2+}+\mathrm{Ca}^{2+}\right)$ in the clays within the aquifer/soil matrix (Rajmohan and Elango 2004).

Based on the diamond-shaped fields of the piper plot, local water samples were grouped into four major facies. The position of the chemical ions offers vital evidence on chemical history of waters and signifies the catchment characteristics. The dominant water types were $\mathrm{Na}-\mathrm{Cl}$ (primary salinity) followed by mixed $\mathrm{CaMgCl}$. Msisi Spring and one sample each from BHs and SDWs (all collected from around Msisi and Mkoyo suburbs) diverted leftwards towards the $\mathrm{CaHCO}_{3}$ type (Fig. 6). The fact that HD retained the same water type in both seasons suggests poor dilution, i.e., no major impacts shown by rainfall (Fig. 6). No samples represented $\mathrm{CaCl}$ and $\mathrm{NaHCO}_{3}$ water while one sample diverted towards $\mathrm{CaNaHCO}_{3}$ type. Except for samples collected from the LSPMA, most SDWs occur together with BHs indicating similar mechanisms (Fig. 6). HD and water collected from the LSPMA area co-existed in the plots which suggests similar water types and evolution mechanisms (Fig. 6). This similarity could partly be due to active HD-groundwater interactions (Shindo 1991) and reinforces the notion that HD salinity is not fully due to ET.

In terms of anions, $\mathrm{Cl}^{-}$had the most abundance followed $\mathrm{HCO}_{3}{ }^{-}$while $\mathrm{SO}_{4}{ }^{2-}$ was completely absent (Fig. 6). The piper diagram shows that the cation and anion triangles were well-defined with most waters falling within the influence of $\left(\mathrm{Na}^{+}+\mathrm{K}^{+}\right)$and $\mathrm{Cl}^{-}$, respectively (Fig. 6). While $\mathrm{Na}-\mathrm{Cl}$ mostly indicated ET controlled water, mixed $\mathrm{CaMgCl}$ represent evolved water, meteoric signature of which was lost by rock-water interactions (Zaidi et al. 2015). Thus, the dominance of $\mathrm{Na}-\mathrm{Cl}$ type could be influenced by the LSPMA (Plate 1) and the extreme semi-arid ET (Shemsanga et al. 2015). This is supported by the fact that water samples collected away from the LSPMA area, and which acted as control like Msisi Spring had $\mathrm{CaHCO}_{3}$ (carbonate hardness type), probably due to rich limestone outcrops locally (Plate 2). Similar findings were reached by (Rwebugisa 2008).

Although MD water was categorized as $\mathrm{Na}-\mathrm{Cl}$, it plotted to the extreme left of HD and closer to most BHs and SDWs collected away from the LSPMA area. Generally, MD was the most mineral free sample with its water chemistry closely approaching the precipitation dominance (Fig. 6). Properties of these less mineralised samples could reflect the normal water chemistry representing the average catchment characteristics other than the LSPMA area. Previous studies got comparable results for the rest of the catchment other than the LSPMA area (Nkotagu 1996; Rwebugisa 2008).

\section{Water usability based on hydrogeochemical parameters, national and WHO guidelines}

An excess conc. of some parameters causes health hazards (WHO 2008). Locally, the abundances of major dissolved ions were highly variable (Table 1) which partly suggests multiple hydrochemical sources and processes influence local water quality (Prasanna et al. 2011).

Water $\mathrm{pH}$ measures the intensity of acidity and/or alkalinity in which all chemical and biological processes depend on (Islam et al. 2016). The results showed that most samples were within the MPLs of both national and WHO standards $(96.43 \%)$ while SN 18 had a high/unsuitable $\mathrm{pH}$ of 9.3 . However, $81 \%$ of the samples were above the natural water $\mathrm{pH}$ range of (4.5-7.0) and suggest possible water quality adjustments (Kaka et al. 2011). Figure 6b shows the spatial distribution of $\mathrm{pH}$ where HD and wells around the LSPMA had higher values while samples further away had $\mathrm{pH}$, approaching local rain $\mathrm{pH}$ of 6 (Shindo 1991; Nkotagu 1996). Thus, the low $\mathrm{pH}$ in $\mathrm{SN} \mathrm{3,} 4$ and 24 could indicate that those areas receive frequent rain recharge which locally has low $\mathrm{pH}$ or are frequently pumped and hence less conc. of dissolved minerals (Napacho and Manyele 2010). The latter was especially exemplified and confirmed by SN 4 which was found to be almost continuously abstracted for irrigation purposes (Filed observations, FGDs). However, organic matter decomposition could also lead to low acidity (Ibid). Assessment of $\mathrm{pH}$ value is crucial as low $\mathrm{pH}$ could indicate presence of toxic metals while higher $\mathrm{pH}$ leads to slippery feel and soda taste in water. Low $\mathrm{pH}$ water is also soft and corrosive and can leach metals from pipes and fixtures like copper, iron, lead, manganese and zinc (Napacho and Manyele 2010; Kaka et al. 2011). Low $\mathrm{pH}$ waters also cause esthetic problems and bitter, metallic to sour taste and can also stain laundry and sanitary sinks (Kaka et al. 2011). 
TDS value is vital for assessing longevity of water in the catchment with high values indicating long residence time (Elisante and Muzuka 2016). The results suggest that most samples had high TDS values which shows longer residence time (Table 1). 88.9 and $18.5 \%$ of the samples were above the recommended WHO and national PL, respectively, and highlights the big differences between the two guidelines. Similar findings were reported by Rwebugisa (2008) and Shindo (1991). Generally, areas of low TDS denote recharge zones and are referred to as young waters, whilst those with high TDS tend to be discharge sites and referred to as old waters (Kaka et al. 2011; Elisante and Muzuka 2017).

High conc. of $\mathrm{Mg}^{2+}$ and $\mathrm{Ca}^{2+}$ causes of higher water alkalinity, high $\mathrm{TH}$, authentic problems and bitter water taste (Napacho and Manyele 2010). Based on TH classification, $66.7,29.3$, and $3.7 \%$ of the local samples were grouped as very hard, hard and moderately hard, respectively (Table 1). This shows that high $\mathrm{TH}$ is a serious problem locally. Previous studies reached similar findings (Shindo 1991; Nkotagu 1996; Rwebugisa 2008). Generally, hard water requires more soap, i.e., extra resources that could be used for other uses in such an area where average households earn <1USD/day (URT 2013). High TH water has also been linked with cardiac disorders (Kaka et al. 2011) hence must be handled with care in such area with ill functioning health services (Ibid).

The results show that $3.7 \%$ of the samples were above $\mathrm{Ca}^{2+}$ PL for both WHO and national standards while 3.7 and $22.2 \%$ of the samples were above the WHO and national $\mathrm{Mg}^{2+}$ guidelines, respectively (Table 1). Consuming water with high $\mathrm{Ca}^{2+}$ affects absorption of other vital minerals and is linked to kidney stones (Eletta et al. 2010). While high $\mathrm{Mg}^{2+}$ in water leads to undesirable taste and a laxative effect (Ibid), low $\mathrm{Mg}^{2+}$ causes increased mortality from cardiovascular diseases and is associated with higher risk of motor neuronal diseases, pregnancy disorders, and preeclampsia. Low $\mathrm{Ca}^{2+}$ in water is linked to risk of neurodegenerative diseases in children, pre-term and low weight births. Shortage of both $\mathrm{Ca}^{2+}$ and $\mathrm{Mg}^{2+}$ in water is associated with some forms of cancer (Napacho and Manyele 2010). The common source of $\mathrm{Ca}^{2+}$ and $\mathrm{Mg}^{2+}$ in groundwater is erosion of limestone and dolomite rocks/minerals, such as calcite and magnetite (Marques et al. 2014). While the catchment is rich in limestone rocks, the relatively low $\mathrm{Ca}^{2+}$ and $\mathrm{Mg}^{2+}$ locally could be due to ordinary softening by cation exchange by $\mathrm{Na}^{+}$rich materials displacing $\mathrm{Ca}^{2+}$ and $\mathrm{Mg}^{2+}$ in solution (Nkotagu 1996).

Table 1 shows that 48.1 and $11.1 \%$ of the samples were above WHO and national PL for $\mathrm{K}^{+}$, respectively. These results suggest that $\mathrm{K}^{+}$is a serious problem locally. In natural environment, however, $\mathrm{K}^{+}$often occurs in low levels owing to its tendency to be fixed by clay minerals and its involvement in the formation of secondary minerals (Pazand et al. 2012). The origin of $\mathrm{K}^{+}$in natural freshwater is weathering of rocks but its conc. often increase in the polluted water due to disposal of wastewater (Pazand et al. 2012). Otherwise, the commonest $\mathrm{K}^{+}$minerals are orthoclase, feldspar, microcline, leucite, biotite in local granites of the area (Nkotagu 1996).

The results show that 72.7 and $11.1 \%$ of samples were above the WHO and national PL for $\mathrm{Na}^{+}$, respectively (Table 1). Thus, $\mathrm{Na}^{+}$was mostly higher than the WHO PL of $8.7 \mathrm{meq} / \mathrm{L}$. High conc. of $\mathrm{Na}^{+}$from most local water samples could be due to long rock-water interactions, high ET, dissolution of halite minerals and weathering of plagioclase feldspar (Pazand et al. 2012). The weathering of plagioclase feldspars (albite) follows Eq. 9. While, low $\mathrm{Na}^{+}$is recommended for hypertension, congenital heart and kidney patients (Napacho and Manyele 2010), local values represent a threat to these vulnerable individuals.

Table 1 shows that 37 and $30 \%$ of the samples were above $\mathrm{NO}_{3}{ }^{-} \mathrm{PL}$ for $\mathrm{WHO}$ and national standards, respectively. The highest $\mathrm{NO}_{3}{ }^{-}$values were found at the LSPMA area which had no sanitation facilities (FGDs and Filed observations). However, the high value of $\mathrm{NO}_{3}{ }^{-}$locally could also be due to oxidation of ammonium formed from sewerage passing through the unsaturated zone, where sufficient $\mathrm{O}_{2}$ diffuses from the atmosphere, causing oxidation of the reduced wastewater (Stumm and Morgan 2012). In contrast, low $\mathrm{NO}_{3}{ }^{-}$in some samples suggests little pollution and/or the underlying natural geology in those areas did not have the anion (Kaka et al. 2011). Since $\mathrm{NO}_{3}{ }^{-}$is extremely water soluble, it is very difficult to manage it once in the catchment (Elisante and Muzuka 2017, 2016). Thus, the best way to deal with $\mathrm{NO}_{3}{ }^{-}$in groundwater system is to avoid catchment contamination. Drinking water with high $\mathrm{NO}_{3}{ }^{-}$leads to methemoglobinemia (blue baby syndrome) (Rebelo et al. 2015). High $\mathrm{NO}_{3}{ }^{-}$is associated with risk of bladder cancer, hypertension, increased infant mortality, central nervous system, birth defects, diabetes, spontaneous abortions, respiratory tract infections, and changes to the immune system (Majumdar and Gupta 2000). Thus, water samples exceeding the PL for domestic and livestock uses should be avoided.

This survey also revealed that 22.2 and $11.1 \%$ of the samples were above the WHO and national PL for $\mathrm{Cl}^{-}$, respectively (Table 1). An excess of $\mathrm{Cl}^{-}$renders a salty taste in water and a laxative effect to people not accustomed to it (WHO 2008). Apart from geological reasons, high $\mathrm{Cl}^{-}$may be due to poor sanitation (Mkude and Saria 2014) and high ET (Shindo 1991). Based on Soltan, (1998) system of classifying water based on $\mathrm{Cl}, \mathrm{SO}_{4}{ }^{2-}, \mathrm{HCO}_{3}$ cons., water sources can be grouped as normal chloride 
( $<15 \mathrm{meg} / \mathrm{L})$, normal sulfate $(<6 \mathrm{meg} / \mathrm{L})$, and normal bicarbonate $(2-7 \mathrm{meq} / \mathrm{L})$ types. By following this method, 78,89 and $74 \%$ of samples could be classified as normal chloride, normal sulfate and normal bicarbonate water types, respectively (Table 1).

While all samples were within the national $\mathrm{SO}_{4}{ }^{2-} \mathrm{PL}$, $11.1 \%$ were above the PL for WHO (Table 1). The low $\mathrm{SO}_{4}{ }^{2-}$ locally suggest limited supply of $\mathrm{SO}_{4}{ }^{2-}$ minerals in the underlying geology (Kaka et al. 2011). Drinking high $\mathrm{SO}_{4}{ }^{2-}$ leads to cathartic, respiratory, diarrhea and dehydration (Subba Rao 1993). Further, high $\mathrm{SO}_{2}{ }^{4-}$, lead to an offensive taste in drinking water, interferes with the efficiency of chlorination in water treatments and increase water corrosiveness (WHO 2008).

\section{Analysis of surface hydrology and recent catchment/ water sources salinity increases}

A clear layer of highly concentrated $\mathrm{NaCl}$-rich lithological unit and limestone rocks were located in the LKR floodplain that drains into HD (Plates 1,2 ). The formation of such layers of salt from near the ET surfaces in dry areas is common, especially when restricted by limited freshwater exchange (Karanth 1994). The study area is classified as semiarid and has very high ET, about $2000 \mathrm{~mm} / \mathrm{yr}$, almost 4 folds the amount of rainfall, (550 mm/yr.) (Shemsanga et al. 2015). To account for high conc. of the $\mathrm{NaCl}-$ materials, craftsmen in Nzuguni, Kitelela and Mahoma Nyika were actively producing table salt from these materials. The salt making process is done by (1) collecting and socking salty soils in jerry cans, (2) vigorously stirring and filtering the mixture to get salt concentrated water, (3) boiling the filtrates to make salts (Plate 1). Between 500 and 1000 craftsmen work in about 60 SPPs (depending on seasonality with the peak of the dry season being more productive/preferred). The fact that the LSPMA occur in the direct drainage to HD, suggests a possible conduit of the salinity to the dam (Fig. 1).

The extent of the soil salinity (conc.) can be appreciated from the fact that $50 \mathrm{~L}$ of filtrated soil water produce about $20 \mathrm{~kg}$ of table salt (Filed observations and FGDs). According to mama Ombeni of Kitelela, the net salt production is slightly higher in the dry season than in the wet season by a difference of $\sim 3 \mathrm{~kg}$ /every $50 \mathrm{~L}$ of filtrated water. FGDs revealed that one individual produces about $50 \mathrm{~kg}$ of salt, which sells for $0.25 \$ / \mathrm{kg}$, an average of $12.5 \$$ in one day. This is considered a good income locally where per capita income is <1USD/day (URT 2013). Thus, the LSPMA are likely to continue for a long time, and in order for them to be sustainable, must be regulated. This is especially the case owing to recurring poor harvests in recent years caused by repeated shortages of rainfall (FGDs). These findings are supported by recent climate trends that show worsening longevity and timing of growing seasons (Shemsanga et al. 2015).

The same area had numerous limestone rocks which were used to make lime powder and employing about 200 craftsmen (Plate 2). Macheyeki et al. (2008) also report that calcium rich (calcrete cement) materials that fill highangle fractures were formed close to the subsurface with alternating periods of flooding and drying, in a geographically low-relief environment within the Bahi depression in which the HD lies. Limestone, a water soluble sedimentary rock, is excavated, broken into small pieces, burned on high heat open furnaces and plenty of water is then added to the heated rocks to break them into powder. These processes increase the surface areas for water dissolution and reaction with minerals and make it easier for runoff to dissolve the salts and carry them downstream to HD. The burning of limestone rocks follows thermal Eq. 13:

$\mathrm{CaCO}_{3}+$ Heat $\leftrightarrow \mathrm{CaO}+\mathrm{CO}_{2}$

(Ghalibaf and Moussavi 2014).

The presence of limestone locally is important since it is the major cause of water hardness (Napacho and Manyele 2010). $\mathrm{CaCO}_{3}$ reacts with $\mathrm{H}_{2} \mathrm{O}$ that is saturated with $\mathrm{CO}_{2}$ to form soluble $\mathrm{Ca}\left(\mathrm{HCO}_{3}\right)_{2}$ according to the Eq. 14: Previous studies also indicated that high water hardness was a serious problem (Shindo 1991; Nkotagu 1996; Rwebugisa 2008).

$\mathrm{CaCO}_{3}+\mathrm{CO}_{2}+\mathrm{H}_{2} \mathrm{O} \rightarrow \mathrm{Ca}\left(\mathrm{HCO}_{3}\right)_{2}$

(Jiang et al. 2012).

Further, limestone dissolves to release $\mathrm{Ca}^{2+}+\mathrm{CO}_{3}^{2-}$ ions (Eq. 15): It is, therefore, not surprising that $\mathrm{HD}$ and most local water sources had high proportions of $\mathrm{HCO}_{3}^{-}$ anions/species (Table 1).

$\mathrm{CaCO}_{3} \leftrightarrow \mathrm{Ca}^{2+}+\mathrm{CO}_{3}^{2-}$

(Jiang et al. 2012).

During heavy rains and mostly when the dam is full, HD water floods back to the catchment including to the LSPMA (i.e. NaCl-rich lithological unit). It is likely that part of salts potentially dissolves, percolate and/or are gradually carried down to HD when its water progressively recedes from ET and/or abstractions (Field observations). The micro-recharge is thought to be responsible for high salinity in the $\mathrm{SG}$ at the $\mathrm{NaCl}$-rich lithological unit (Fig. 1, Table 1). The likelihood of the micro-recharge was supported by the spatial distribution of EC where areas around $\mathrm{NaCl}$-rich lithological unit had high EC while those further away had lower EC values (Fig. 2a). However, HD observes a slight dilution with less mineralised/fresh runoff where EC and $\mathrm{pH}$ dropped by about $708 \mu \mathrm{Scm}^{-1}$ and 0.5 , respectively (Table 1). As ET continues to remove water from the dam, freshwater molecules escapes, leaving more salt ions hence HD progressively becomes saltier again. 
However, even during the wet season, HD retained relatively higher salinity (EC) than recommended values for irrigation and domestic (Table 1). Thus, the idea that HD salinity is fully due to dam surface ET is uncertain and highly disputed. It was clear that the salts were coming with runoff prior to being concentrated by ET. The chemistry of the SG within the LSPMA was ET dominated and explains why HD water was in the same category. Thus, the local groundwater quality is associated with high ET and HD-groundwater interactions (Shemsanga et al. 2015).

At this point, the claim that HD is recently saltier remains unresolved. However, HIS only started in 1995 and mostly operates during wet and a few months thereafter (when the water is less salty) (Field observations and personal communication with Mr. Ntuza). HIS brought in a new factor that withdraws water and largely reduce HD volume when the salinity is relatively low and could account to recently increased salinity. Similarly, from 1921 to 2014 , there was a decline of about $54 \mathrm{~mm}$ of annual rains. Shemsanga et al. (2015) showed that except for $6 \mathrm{~mm}$ of rains recorded in 2009, there had been no May rains from 1991 to 2014 whereas May used to contribute significantly to HD in previous years. This trend means less freshwater in the catchment and poor HD dilution hence increased salinity recently. Furthermore, Field observations revealed several runoff diversions upstream of HD. These diversions trap runoff flowing to HD (Shemsanga et al. 2015). The fact that the diversions were mostly from saltfree areas, means less freshwater to HD and more solutes per unit dam volume. It is also argued that HD level has reduced recently owing to these diversions (FGDS and Personal communication with Mr. Ntuza).

A recent study also indicated a warming trend where between 1964 and 2014, $T_{\min }$ increased for about $1.13{ }^{\circ} \mathrm{C}$ (Shemsanga et al. 2015). The warming in turn triggers more ET, which implies additional water losses and concentrating catchment's salinity, including in HD. This could further explain recent HD salinity increases corresponding to increasing PET/T and decreasing rainfall. The local warming is crucial as, $\mathrm{T}$ and ET are highest in wet months hence more water losses (Ibid). This is especially worrisome since wind, another factor driving ET, is also highest during wet months and local rains are often interrupted by strong sunhours (Ibid). These characteristics explain the lack of permanent water bodies, except for HD which partly receives groundwater (Shindo 1991). These factors are argued to have reduced HD level to the average of $4.5 \mathrm{~m}$ compared to the original design of $9 \mathrm{~m}$ (personal communication with Mr. Ntuza). However, HD sediments account for large part of the dam volume which exposes enormous dam volume to direct ET forces/losses.
The gradual increase in groundwater salinity is also not fully resolved at this time. However, poor recharge due to low rains and/or high ET leads to unlocking of deeper groundwaters that tend to be mineral richer leading to pumpage of deeper waters in contact with rock matrices (Tularam and Krishna 2009). Since local recharge highly depends on local rainfall; the decreasing rains have the potential of affecting groundwater quality (Taylor et al.2012, Shemsanga et al. 2015). Decreasing rains/ recharge is supported by local groundwater level trends (Shemsanga et al. 2015). Similarly, there are active HDaquifer interactions; thus the gradual groundwater salinity increase could originate from HD salinity increases (Shemsanga et al. in preparation). This is supported by the fact that most wells close to HD had saltier waters while wells far away, and which acted as controls, had low salinity (Shemsanga et al. in preparation). It is worth mentioning that $\mathrm{HD}$ is a prominent discharge site for Makutupora aquifer, the main aquifers supplying water in DM. The possibility of these two water masses mingling requires careful understanding of these water components and further shows the need for holistically managing water resources, i.e., integrated water resources management (URT 2009).

\section{Comparison of water suitability/compositions between HD and MD}

The origin and mechanisms of high salinity in HD can be appreciated when compared to a nearby MD (only about $38 \mathrm{~km}$ apart). MD, also an earthen dam, is located within climatologically similar area and thus faces more-or-less similar climatological forces, including high ET rates. However, MD had very low EC $\left(209 \mu \mathrm{Scm}^{-1}\right)$ and $\mathrm{pH}$ (6.6) compared to (3298-4006 $\left.\mu \mathrm{Scm}^{-1}\right)$ and (8-8.5) of HD (Table 1). Similarly, MD had low conc. of all chemical water quality parameters, particularly, $\mathrm{Na}^{+}, \mathrm{HCO}_{3}{ }^{-}$and $\mathrm{Cl}^{-}$ions that especially characterize HD (Table 1). Most MD hydrogeochemical parameters were closer to local rain values suggested by Shindo (1991). Thus, HD high salinity is not fully a function of high PET rates but rather a physical source entering the dam.

\section{Salt and limestone manufacturing and environmental degradation}

Although LSPMA give locals a good income, they use a lot of fuel wood for which case most trees have been cleared (Plate 1 and 2). The extent of land cover clearance is so significant that not enough fuel wood is currently available and locals use cattle droppings, agricultural remains, grasses, leaves, twigs and poles to supply energy in the stoves (Field observations and personal communication 
with Bibi Ekisa Nkazumwa, Elis Malambati of Nzuguni suburb). The deforestation has major environmental implications, particularly by triggering erosion and sedimentation of HD and must be managed (Field observations and personal communication with Mr. Ntuza). Severe catchment modification is also linked to higher runoff and reduced infiltration (Valimba 2004) hence may affect groundwater recharge locally. Recent discoveries of natural gas in the southern part of the country (Demierre et al. 2015); can supply needed energy and slow down deforestation rates. Furthermore, instead of using open furnaces to produce lime powder, energy saving stoves and closed furnaces which use less wood like the ones used to make local mud bricks can be adopted (URT 2015). FGD also reveals that there were no sanitation facilities in the LSPMA area and craftsmen mostly relieved themselves in the bushes. This trend is supported by water quality data where the two SDWs from LSPMA area had highest $\mathrm{NO}_{3}{ }^{-}$ of 5.23 and 7.37, respectively, compared to the catchment average of $1.13 \mathrm{meq} / \mathrm{L}$ (Table 1$)$.

\section{Irrigation water suitability based on existing indices and physico-chemical parameters}

Suitability of water for irrigation is a function of its mineral compositions (Table 2). The quality of water can have an adverse impact on soil/crop productivity. An excess of even small amounts of some salts, but when applied for a long time, coupled with poor agricultural practices and drainage, may radically affect soils (Inayathulla and Paul 2013). High conc. of $\mathrm{Na}^{+}$in water reduces soil permeability and soil/crop productivity (Ibid). Hence, assessment of $\mathrm{Na}^{+}$conc. in irrigation water is crucial and is often represented as $\% \mathrm{Na}$. Table 2 shows that, $77.7 \%$ of the samples were grouped as excellent $(3.7 \%)$, good $(7.4 \%)$ or permissible (59.3\%). However, $(7.7 \%)$ and $(3.7 \%)$ of samples were classified as doubtful and unsuitable, respectively, and could harm crops/soils. These include HD samples (70.5-78.4\%, C4), the two SG samples from the LSPMA (76.3-79.6, C4) and SN 18 (91.8\%, C5) and should be avoided for irrigation. Generally, water with $\mathrm{Na} \%$ of $>60 \%$ may result in $\mathrm{Na}$ accumulation and deterioration of soil structure, infiltration and aeration rates (Inayathulla and Paul 2013). Further analysis of MD water shows that its EC, \% Na, SRC, $\mathrm{KR}$ values were all acceptable which is a sharp contrast to HD where most of these parameters were unacceptable and/or doubtful (Table 2). The unfitness of HD water for irrigation is distressing as it already employs 468 farmers in the HIS which supports an annual per capita income of $4000 \$(1,171,200 \$$ of annual local income) (Personal communication with Mr. Ntuza). Thus, sustainability of HD is vital to the populace.
By using SAR index, nearly all samples were either excellent (S1, 85.2\%) or good (S2, 3.7\%), i.e., suitable for all crops and soils (Inayathulla and Paul 2013). In contrast, $55.6 \%$ of the local samples had KR of $>1$ hence unfit for irrigation (Inayathulla and Paul 2013). These include HD samples for both seasons and challenge its main objective as a source of irrigation water (Table 2). RSC significantly influences irrigation water $\mathrm{pH}, \mathrm{EC}$ and $\mathrm{SAR}$ values. Water with RSC of $>2.5 \mathrm{meq} / \mathrm{L}$ leads to salt build up which clogs soil pores and hinders air and water movements (Inayathulla and Paul, 2013). Locally, 96\% of the samples were in $\mathrm{C} 1$ suggesting fitness for irrigation while 1 sample ( $\mathrm{SN}$ 18) was unfit with a value of $3.031 \mathrm{meq} / \mathrm{L}$ (Table 2). In addition, most samples $(88.9 \%)$ had -ve RSC notations suggesting even desirable fitness for irrigation. - ve RSC reduces soil $\mathrm{Na}$ hazard since adequate $\mathrm{Ca}^{2+}$ and $\mathrm{Mg}^{2+}$ would be in surplus of what will be precipitated as carbonates hence their exclusion from water (Sadashivaiah et al. 2008).

While these indices are useful, they only give empirical conclusions; and other factors are equally crucial to consider. These include climate, crop salinity tolerance, soil types/ permeability, rainfall characteristics and irrigation methods (Mulwa et al. 2013). For instance, different crops have different salt tolerance and farmers may need to adapt to specific crops. Well-drained soils may render unsuitable water to be fairly usable. Locally, however, this is unlikely due to low rains (about $550 \mathrm{~mm} / \mathrm{yr}$.) hence poor drainage (Shemsanga et al. 2015). A combination of several indices, however, helps to effectively map unsuitable water sources (Mulwa et al. 2013). Thus, by combining these indices, it can be concluded that HD and SN 18 were among the most problematic and should be handled with care while MD was among the best (Tables 1 and 2).

Although high $\mathrm{HCO}_{3}{ }^{-}$is not toxic to plants, conc. of $>2$ $\mathrm{meg} / \mathrm{L}$ causes Zinc deficiency in rice (Asiwaju-Bello et al. 2013). Locally, 96.3\% of samples, including HD had values of $>2 \mathrm{meq} / \mathrm{L}$ (Table 1 ). While rice is currently not a common crop, these results are useful if rice cultivation will be sought in the future. Furthermore, high $\mathrm{HCO}_{3}{ }^{-}$in water lead to precipitation of insoluble $\mathrm{Mg}^{2+}$ and $\mathrm{Ca}^{2+}$ in soils, thus leaving higher abundances of $\mathrm{Na}$ i.e. increase in the SAR ratio (Mulwa et al. 2013, Asiwaju-Bello et al. 2013). Locally, natural sources like the reaction of carbonate minerals with carbon dioxide gas $\left(\mathrm{CO}_{2}\right)$ and dissolution of $\mathrm{CO}_{2}$ may be the origin of bicarbonate water based on Eqs. 16 and 17:

$$
\begin{aligned}
& \mathrm{CaCO}_{3}+\mathrm{CO}_{2}+\mathrm{H}_{2} \mathrm{O} \rightarrow \mathrm{Ca}^{2+}+2 \mathrm{HCO}_{3} \\
& \mathrm{CO}_{2}+\mathrm{H}_{2} \mathrm{O} \rightarrow \mathrm{H}^{+}+\mathrm{HCO}_{3}
\end{aligned}
$$

While water with $\mathrm{CO}_{3}{ }^{2-}$ of $>0.1 \mathrm{meq} / \mathrm{L}$ is unsuitable for irrigation (Mulwa et al. 2013), 92.6\% of samples had conc. 
of $<0.1 \mathrm{meq} / \mathrm{L}$ while $7.4 \%$ had values $>0.1 \mathrm{meq} / \mathrm{L}$ and were exemplified by HD for the dry season and SN 18 that was problematic with most other indices (Table 2). However, low $\mathrm{CO}_{3}{ }^{2-}$ water is common in low $\mathrm{pH}$ environments (Elisante and Muzuka 2016).

While recommended $\mathrm{Cl}^{-}$in irrigation water is $<4.0 \mathrm{meq} / \mathrm{L}$ (Ayers and Westcot 1985), $70.4 \%$ of local water samples were unsuitable, including from HD (Table 1). This shows that high $\mathrm{Cl}^{-}$is a serious problem locally and water should be used with care if the soils are to remain productive. According to Stuyfzand, (1989), $\mathrm{Cl}^{-}$is usually classified as $(<0.14)$ Extremely fresh; $(\mathrm{C} 1),(<0.14)$ Very fresh; (C2), (0.14-0.85) Fresh (C3), (0.85-4.23), Fresh brackish; (C4), (4.23-8.46) Brackish; (C5), (8.46-28.21) Brackish Salt; 28.21-564.13) (C6), Hypersaline, >564.13 (C7). Locally, 0, 0, 29.6, 14.8, 48.1, 7.4 and $0 \%$ of samples were grouped into $\mathrm{C} 1$ to $\mathrm{C} 7$, respectively. The majority (48.1\%) were brackish and unsuitable for most uses (Table 1). The two SG from LSPMA, $7.4 \%$, fell under (C6, Hypersaline). Other samples were either in C4 (14.8\%) or C3 (29.6\%) (Table 1). Apart from the geological reasons, the relatively higher $\mathrm{Cl}^{-}$could be attributed to atmospheric deposits, pollution (Kaka et al. 2011). A recent study showed that the municipal WWSP found within the same catchment had very low efficiency (Mkude and Saria 2014).

For water to be suitable for irrigation, $\mathrm{pH}$ should range from 6.5 to 8.4 (Naseem et al. 2010). While $92.6 \%$ of samples were fit for irrigation, HD for the dry season and SN 15, (Table 1) had high $\mathrm{pH}$ values 8.5 and 9.3, respectively, and challenge the objective of HD as a source of irrigation water. During the wet season, $\mathrm{pH}$ for HD dropped to 8.0 indicating a slight shift towards slim acceptability owing to limited rain dilution which locally has low $\mathrm{pH}$ values (Shindo 1991; Nkotagu 1996).

The extent of dissolved ions locally was indicated by high EC values (Table 1). High EC variations were observed with the SG in the LSPMA having the highest, while MD had the least (Table 1). Generally, the higher the EC/TDS the poorer is the salinity hazard (Islam et al. 2016). High EC in water leads to the inability of plants to compete with ions in the soil (Inayathulla and Paul 2013). In terms of irrigation suitability, $55.6 \%$ of the samples presented average (C3) while $37 \%$ were under $\mathrm{C} 4$ (bad for irrigation). HD had high EC of 3298 and $4006 \mu \mathrm{Scm}^{-1}$ for wet and dry seasons, respectively, which suggests poor rainfall dilution and/or the water feeding the dam was already saline with both seasons having C4 waters (Table 1). Thus, HD water was mostly unsuitable for irrigation and should it be necessary to use its waters, mixing it with runoff may be required to lower its EC to $<2250$ $\mu \mathrm{Scm}^{-1}$. Note that MD water scored $\mathrm{C} 1$ and offers a sharp contrast with HD, C4 (Table 1). Similarly, Msisi spring had low EC of about $660 \mu \mathrm{S} \mathrm{cm}^{-1}$ which suggest low dissolved ions, possibly as a result of shorter water-rock interactions due to good aquifer permeability and steeper slopes leading to rapid groundwater flow (Elisante and Muzuka 2016). In order to understand HD salinity mechanisms further, a tributary leading to HD from the LSPMA area was periodically measured for EC and high values (C4) of $\left(7880,7690,8789\right.$ and $\left.8670 \mu \mathrm{Scm}^{-1}\right)$ were recorded in April, 2014 hence confirming poor rainfall dilution of the salts.

Water with TDS of $<1000 \mathrm{ppm}$ is regarded as fresh and doesn't affect the soil solution osmotic pressure (Al-Tabbal and Al-Zboon 2012). Locally, 63\% of samples had TDS of $>1000 \mathrm{ppm}$ hence useless to irrigators (Table 1). Notice that, although HD is frequently/ideally used for irrigation particularly grapes, its TDS values were $>1000 \mathrm{ppm}$ for both dry and wet seasons. This might suggest that the soils irrigated with such waters will be adversely impacted which can also explain poor crop harvests locally, including grape (FGDs, field observations and personal communication with HIS officers, village leaders, and farmers).

\section{Study water and its suitability for grape irrigation}

Since HD is mainly used for grape vine irrigation and that grape plants are sensitive to $\mathrm{EC}, \mathrm{Na}^{+}$and $\mathrm{Cl}^{-}$(Tanji and Kielen 2002; Stevens et al., 2012); this study specifically assessed HD water suitability for grape irrigation. From EC parameter, HD water for both wet and dry seasons were unsuitable for grape irrigation while based on $\mathrm{Cl}^{-}$, only HD sample for dry season was unsuitable (Table 1). High salinity affects vine productivity by reducing their capability to take up water and eventually via physical damages when the conc. of ions reach toxic levels (Pitt and Stevens 2012).These results generally challenge the main objective of HIS and can be among the reasons for reported poor grape productivity in Hombolo suburb (FGDs). Similarly, owing to high salinity in many SDWs, farmers and herders in Nzuguni, Kitelela, Mahoma Nyika and Mahoma Makulu diverted runoff into some SDWs so as to dilute the salinity and make them suitable for irrigation, livestock and domestic uses (Field observations and FGDs).

\section{Conclusions and recommendations}

The mechanisms controlling water quality in HD and its catchment were undertaken to assess the origin of high dam salinity that was debated for over 20 years but remained unclear. Water-rock interactions and high ET were found to affect the quality of different water sources. A layer of $\mathrm{NaCl}$-rich lithological unit was found about 5-7 km upstream of $\mathrm{HD}$ amongst limestone rocks. These materials 
were in the floodplain draining to HD. During heavy rains, the area often floods with runoff and water from HD and dissolves the salts/materials. The salty water, then recharges the aquifer and/or flows back to HD. This mechanism was supported by the spatial EC distribution (which showed that the $\mathrm{NaCl}$-rich lithological unit area had highest EC while samples far away, and which acted as controls, like Msisi Spring had the least). The dominant water type was $\mathrm{Na}-\mathrm{Cl}$ followed by mixed $\mathrm{CaMgCl}$ and $\mathrm{CaHCO}_{3}$ in that order. Specifically, HD and SG close to the dam had $\mathrm{Na}-\mathrm{Cl}$ type and mostly controlled by ET; which is common for dry and semi-arid climate.

Certain water quality parameters (mostly $\mathrm{NO}_{3}{ }^{-}$and EC) in some water sources were above the MPLs for domestic, livestock and agricultural uses and it was clear that some local people were mostly consuming water of unknown quality. This has the potential of affecting human and livestock health, but also the soils/crops irrigated with the unsuitable waters. Thus, imminent adverse impacts on soils are highly likely as the catchment is also not well drained due to low rains $(550 \mathrm{~mm} / \mathrm{yr}$.) and has decreasing rain trends and high ET (2000 mm/yr.).

Unlike MD, HD was highly saline with higher $\mathrm{pH}$. However, the dams are only $38 \mathrm{~km}$ apart with similar climate, hence if the dam surface ET was the major factor for HD high salinity, comparable trends would be recorded in $\mathrm{MD}$, which wasn't the case. MD had a relatively low $\mathrm{pH}$ (6.6) and EC (209 $\left.\mu \mathrm{Scm}^{-1}\right)$ compared to HD (8-8.5) and $\left(3298-4006 \mu \mathrm{Scm}^{-1}\right)$ respectively. This further suggests that high PET locally is not the primary and only reason for the high salinity in HD.

Recent increased water withdrawal from HD and adverse shifts in climatic trends, i.e., decrease rainfall and warming trends were also associated with worsening catchment's salinity. While, rising ET and warming remove freshwater and leave behind concentrated salts, low rains reduce dam volume, mainly from salt-free mountainous areas which feeds the dam and the catchment.

HD water and some wells in the near vicinity of the LSPMA were among the most problematic in terms of irrigation suitability. Although HD is principally used for grape vine irrigation, multiple parameters assessed, including EC and $\mathrm{Cl}^{-}$clearly showed that its water was unsuitable for grape irrigation. $\% \mathrm{Na}$, in particular, suggests that HD was unsuitable for irrigation and so was SG from the LSPMA area. Unlike HD, MD was mostly permissible under KR, SAR, RSC and \%Na indices. Should HD water be used for irrigation, it should be mixed with fresh runoff to dilute the salinity. Small earthen dams can be built for that purpose. It was further recommended that HD sediments be removed and deposition of new sediments be controlled to enable it to hold more water and reduced water exposed to direct ET. Similarly, drip irrigation and other water-saving irrigation methods should be adopted. Finally, efforts should be made to educate irrigators on the agrarian system on the harms of continued use of saline waters.

Open Access This article is distributed under the terms of the Creative Commons Attribution 4.0 International License (http:// creativecommons.org/licenses/by/4.0/), which permits unrestricted use, distribution, and reproduction in any medium, provided you give appropriate credit to the original author(s) and the source, provide a link to the Creative Commons license, and indicate if changes were made.

\section{References}

Al-Tabbal JA, Al-Zboon KK (2012) Suitability assessment of groundwater for irrigation and drinking purpose in the Northern Region of Jordan. J Environ Sci Technol 5(5):274-290

Asiwaju-Bello YA, Olabode FO, Duvbiama et al (2013) Hydrochemical evaluation of groundwater in Akure Area, south-western Nigeria, for irrigation purpose. Eur Int $\mathbf{J}$ Sci Technol 2(8):235-249

Ayers RS and Westcot DW (1985) Water quality for Agriculture, Irrigation and Drainage, Paper No. 29, Rev.1, FAO, Rome, 174

Biswas AK (2004) Integrated water resources management: a reassessment: a water forum contribution. Water international 29(2):248-256

Biswas AK (2008) Integrated water resources management: is it working? Water Resour Development 24(1):5-22

Chadha DK (1999) A proposed new diagram for geochemical classification of natural waters and interpretation of chemical data. Hydrogeol J 7(5):431-439

Demierre J, Bazilian M, Carbajal J, Sherpa S, Modi V (2015) Potential for regional use of East Africa's natural gas. Appl Energy 143:414-436

Eletta OAA, Adeniyi AG, Dolapo AF (2010) Physico-chemical characterisation of some ground water supply in a school environment in Ilorin, Nigeria. Afr J Biotechnol 9(22):3293-3297

Elisante E, Muzuka ANN (2016) Assessment of sources and transformation of nitrate in groundwater on slopes of Mount Meru, Tanzania. Environ Earth Sci 75(3):277: DOI: 10.1007/ s12665-015-5015-1

Elisante E, Muzuka ANN (2015) Occurrence of nitrate in Tanzanian groundwater aquifers: a review. Applied Water Science 7(1):71-87

Fisher RS, Mullican WF III (1997) Hydrochemical evolution of sodium-sulfate and sodium-chloride groundwater beneath the northern Chihuahuan Desert, Trans-Pecos, Texas, USA. Hydrogeol J 5(2):4-16

Ghalibaf MB, Moussavi Z (2014) Development and environment in Urmia Lake of Iran. Eur J Sustain Dev 3(3):219-226

Gibbs RJ (1970) Mechanisms controlling world water chemistry. Science 170(3962):1088-1090

Goldammer T (2015) The Grape Grower's Handbook: A Guide to Viticulture for Wine Production. Apex

Gupta J, Pahl-Wostl C, Zondervan R (2013) Glocal water governance: a multi-level challenge in the anthropocene. Curr Opin Environ Sustain 5(6):573-580

Hatibu N, Mahoo H (1999) Rainwater harvesting technologies for agricultural production: a case for Dodoma, Tanzania. Conservation tillage with animal traction. In: Kaumbutho PG, Simalenga TE (eds) 1999. Conservation tillage with animal 
traction. A resource book of the Animal Traction Network for Eastern and Southern Africa (ATNESA). Harare. Zimbabwe p 161-171. http://www.atnesa.org/contil/contil-hatibuwaterharvesting-TZ.pdf.

Inayathulla M, Paul JM (2013) Water quality index assessment of ground water in Jakkur sub watershed of Bangalore, Karnataka, India. Int $\mathrm{J}$ Civil Struct Environ Infrastruct Eng Res Dev 1(3):99-108

Islam MJ, Fancy R, Rahman MS et al (2016) Evaluation of Physicochemical characteristics of rainy season groundwater of Dinajpur Sadar Upazila in Bangladesh. J Environ 11(1):17-24

Jalali M (2007) Hydrochemical identification of groundwater resources and their changes under the impacts of human, activity in the Chah Basin in Western Iran. Environ Monit Assess 130:34-364

Jiang J, Huo Z, Feng S, Zhang C (2012) Effect of irrigation amount and water salinity on water consumption and water productivity of spring wheat in Northwest China. Field Crops Research 137:78-88

Kaka EA, Akiti TT, Nartey VK, Bam EPK, Adomako D (2011) Hydrochemistry and evaluation of groundwater suitability for irrigation and drinking purposes in the southeastern Volta river basin: manyakrobo area, Ghana. Elix Agric 39:4793-4807

Karanth KR (1994) Groundwater assessment development and management. McGraw-Hill Publishing Co., Ltd., New Delhi

Kaur R, Singh RV (2011) Assessment for different groundwater quality parameters for irrigation purposes in Bikarner city, Rajastan. J Appl Sci Environ Sanit 6(3):385-392

Kumar CP (2013) Recent studies on impact of climate change on groundwater resources. Int J Phys Soc Sci 3(11):189-221

Macheyeki AS, Delvaux D, De Batist M, Mruma A (2008) Fault kinematics and tectonic stress in the seismically active Manyara—Dodoma Rift segment in Central Tanzania-Implications for the East African Rift. J Afr Earth Sci 51:163-188

Majumdar D, Gupta N (2000) Nitrate pollution of groundwater and associated human health disorders. Indian Journal of Environmental Health 42(1):28-39

Marques JM, Matias MJ, Basto MJ, et al (2014) Water-rock interaction responsible for the origin of high $\mathrm{pH}$ mineral waters (S. Portugal). Dams Appurtenant Hydraul Struct: 293

Mkude IT, Saria J (2014) Assessment of waste stabilization ponds (WSP) efficiency on wastewater treatment for agriculture reuse and other activities a case of Dodoma municipality, Tanzania. Ethiop J Environ Stud Manag 7(3):298-304

Mulwa JK, Mwega BW, Kiura MK (2013) Hydrogeochemical analysis and evaluation of water quality in Lake Chala catchment area, Kenya. Global Adv Res J Phys Appl Sci 2(1):1-7

Napacho ZA, Manyele SV (2010) Quality assessment of drinking water in Temeke District (part II): characterization of chemical parameters. Afr J Environ Sci Technol 4(11):775-789

Naseem S, Hamza S, Bashir E (2010) Groundwater geochemistry of Winder agricultural farms, Balochistan, Pakistan and assessment for irrigation water quality. Eur Water 31:21-32

Neill H, Gutierrez M, Aley $T$ (2004) Influences of agricultural practices on water quality of Tumbling Creek cave stream in Missouri. Environ Geol 45(4):550-559

Nkotagu H (1996) The groundwater geochemistry in a semi-arid, fractured crystalline basement area of Dodoma, Tanzania. J Afr Earth Sci 23(4):593-605

Parmar VM (2013) A review on various techniques and parameters signifying purity of water. Innov J Food Sci 1(1):8-14

Pazand K, Hezarkhani A, Ghanbari Y, Aghavali N (2012) Groundwater geochemistry in the Meshkinshahr basin of Ardabil province in Iran. Environ Earth Sci 65(3):871-879

Piper AM (1944) A graphic procedure in the geochemical interpretation of water analysis. Trans Am Geophys Union 25:914-923
Prasanna MV, Chidambaram S, Gireesh TV, Ali TJ (2011) A study on hydrochemical characteristics of surface and sub-surface water in and around Perumal Lake, Cuddalore district, Tamil Nadu, South India. Environ Earth Sci 63(1):31-47

Rajmohan N, Elango L (2004) Identification and evolution of hydrogeochemical processes in the groundwater environment in an area of the Palar and Cheyyar River Basins, Southern India. Environ Geol 46(1):47-61

Rebelo JS, Almeida MD, Vales L, Almeida CM (2015) Presence of nitrates in baby foods marketed in Portugal. Cogent Food Agric 1(1):101-114

Rwebugisa RA (2008) Groundwater recharge assessment in the Makutupora Basin, Dodoma, Tanzania, M.Sc. Thesis. International Institute for Geo-Information Science and Earth Observation, Enschede

Sadashivaiah C, Ramakrishnaiah C, Ranganna G (2008) Hydrochemical analysis and evaluation of groundwater quality in Tumkur Taluk, Karnataka State, India. Int J Environ Res Public Health 5(3): $158-164$

Sami K (1992) Recharge mechanisms and geochemical processes in a semi-arid sedimentary basin, Eastern Cape, South Africa. J Hydrol 139:27-48

Shemsanga C, Muzuka ANN, Martz L, Komakech H, Omambia AN (2015) Statistics in Climate Variability, Dry Spells, and Implications for Local Livelihoods in Semiarid Regions of Tanzania: The Way Forward. In: W-Y Chen et al. (eds) Handbook of Climate Change Mitigation and adaptation. Springer, New York. doi:10.1007/978-1-4614-6431-0_66-1

Shemsanga C, Muzuka ANN, Martz L, and Komakech HC (in preparation) Mapping groundwater provenance and hydrogeological dynamics in semi-arid aquifers of Dodoma municipality using stable isotopes of water and hydrogeochemical facies. Under review. J Environ Earth Sci. Springer Media

Shindo S (1991) Study on the recharge mechanism and development of groundwater in the Inland Area of Tanzania. Report of the Japanese-Tanzanian Research Mission (3). Chiba University

Soltan ME (1998) Characterisation, classification, and evaluation of some ground water samples in upper Egypt. Chemosphere 37(4):735-745

Stevens RM, Pitt TR, Dyson C (2012) Managing soil salinity in groundwater irrigated vineyards. Final Report to the National Program for Sustainable Irrigation. Project Number: CIF5121, pp 79

Stumm W, Morgan JJ (2012) Aquatic chemistry: chemical equilibria and rates in natural waters (Vol. 126). Wiley, New York, p 1040

Stuyfzand PJ (1989) Nonpoint source of trace element in potable ground water in Netherland. In: Proceeding of the $18^{\text {th }}$ TWSA Water Working, Testing and Research Institute, KIWA, Nieuwegein, The Netherlands

Subba Rao N (1993) Environmental impact of industrial effluents in groundwater regions of Visakhapatnam Industrial Complex. Indian J Geol 65(1):35-43

Tanji KK, Kielen NC (2002) Agricultural drainage water management in arid and semi-arid areas. FAO 508 Vikas Ramteke and A. J. Sachin Publications. 135

Taylor RG, Todd MC, Kongola L et al (2012) Evidence of the dependence of groundwater resources on extreme rainfall in East Africa. Nat Clim Change 3:374-378

Tularam GA, Krishna M (2009) Long-term consequences of groundwater pumping in Australia: a review of impacts around the globe. J Appl Sci Environ Sanit 4(2):151-166

URT (United Republic of Tanzania) (2002) Sustainable development of groundwater resources -assessment of nitrate pollution to Makutupora basin, Dodoma, Tanzania. Ministry of water and Livestock. Technical review meeting Vienna, Austria 27-31 May, 2002 
URT (United Republic of Tanzania) (2007) The Environmental Management Act (CAP. 191) Regulations. The environmental management (water quality standards) regulations, 2007. Government Printers, Dar-es-Salaam

URT (United Republic of Tanzania); (2009) Water Resources Management Act of (2009). Government Printers, Dar-esSalaam

URT (United Republic of Tanzania); (2013) The 2012 population and housing census population of Tanzania. Tanzania Bureau of Statistics. Government Printers, Dar-es-Salaam

URT (United Republic of Tanzania); (2015) Analysis of energy and carbon intensities of common buildingmaterials used in Tanzania: Provision of Affordable Housing. Dar- es-Salaam.
Valimba P (2004) Rainfall variability in southern Africa, its influences on stream flow variations and its relationships with climatic variations, Rhodes University, UK. https://core.ac.uk/ download/pdf/11984356.pdf. Accessed 28 Aug 2014

World Health Organization (WHO) (2008) WHO guidelines for drinking water quality, incorporating the first and second addenda, vol 1. Recommendations, WHO, Geneva

Zaidi FK, Nazzal Y, Jafri MK, Naeem M, Ahmed I (2015) Reverse ion exchange as a major process controlling the groundwater chemistry in an arid environment: a case study from northwestern Saudi Arabia. Environ Monit Assess 187(10):607 